\title{
East Asian Summer Monsoon Rainfall Variability and Climate Teleconnection
}

\author{
By K.-M. Lau \\ Laboratory for Atmospheres, NASA/Goddard Space Flight Center, Greenbelt, MD 20771, U.S.A. \\ (Manuscript received 6 July 1991, in revised form 10 September 1991)
}

\begin{abstract}
In this paper, recent progress in the study of the East Asian summer Monsoon (EAM) and its impact on global climate fluctuations are reviewed. The review is focused on the climatology and variability of the EAM rainfall and its relationship with regional and global scale circulation systems. Climatologically, the EAM rainfall is dominated by convective activities associated with the northward advance of the $M e i-Y u$ trough from southern China during April-May to central China during midJune. After staying in the same position for one to two weeks, the $M e i$ - $Y u$ trough disappears abruptly and a new rainfall zone is developed over northern China. This is followed by a quasi-20 days oscillatory rainfall regime which develops over central China. Subsequently, the maximum rainfall zone returns to the coastal region of south and southeast China. Regional features unique to the EAM include the extraordinary length of the extended monsoon season (April to late August), the extent of the northward penetration of the major precipitation, the multiple onset and interspersed propagation and stationary nature of the rainfall. Planetary scale features that directly influence the EAM include the western Pacific Subtropical High, the Tibetan High, the local Hadley and the equatorial Walker circulations.

It is stressed that the EAM rainfall is only a small part of global scale precipitation system which migrates northward from the equatorial Indian Ocean and the Western Pacific to the EAM region and Indian subcontinent during the boreal summer. The EAM possesses a wide range of spatial and temporal scales of variabilities including the seasonal cycle, intraseasonal oscillations, subseasonal scale inter-monsoon interactions, sub-synoptic scale variability and supercluster organization in the western Pacific. These variabilities are in turn linked to interannual variations associated with the biennial oscillation and the El Nino/Southern oscillation. Also discussed is evidence showing the presence of an atmospheric teleconnection pattern connecting eastern Asia and North America (ANA) via the North Pacific. The ANA has profound impact on the climate of eastern Asia including Japan. Dynamically, it may be associated with a marginally unstable barotropic mode in the mean northern hemisphere summertime circulation. This mode is also related to latent heating in the western Pacific near Philippines as well as the Indian Ocean region. While there are some successes in the general circulation model (GCM) simulation of the planetary scale features of the EAM, most GCMs still have problems obtaining realistic regional rainfall over East Asia and India. The intraseasonal and interannual variability of the EAM are generally not very well-simulated in GCMs. Much work is needed to improve modeling of the variability of the EAM.
\end{abstract}

\section{Introduction}

The East Asian Monsoon (EAM) is an integral component of the earth climate system. Not only does the EAM affect the climate of East Asia and the adjacent areas, it also exerts strong influence on climate in regions far remote from East Asia. The EAM has two subsystems, i.e., a winter and a summer component. Lau and Li (1984) presented a survey of both components of the EAM in the context of an evolving global scale phenomenon. In this paper, we focus on the northern hemisphere summer.

(C)1992, Meteorological Society of Japan
Subsequent reference to the EAM will mean the summer component only. As part of the global monsoon system, the EAM is closely linked to the Indian monsoon and the western Pacific circulation in a variety of time scales ranging from the subseasonal to the interannual (Lau and $\mathrm{Li}, 1984$ ).

The summertime climate over Indo-China, East China, Japan and Korea are strongly dependent upon the synoptic and mesoscale fluctuations in the monsoon trough, known as the $M e i-Y u$ (Chinese) or Baiu (Japan) and Chang-mai (Korea). These different nomenclatures describe different phases of the same monsoon system with different local charac- 
teristics. Within the $M e i-Y u$, there are interacting mesoscale convective systems ranging from meso- $\alpha$, $-\beta,-\gamma$ to synoptic scale disturbances, resulting in one of most complex rain system on earth. The EAM is also strongly affected by intraseasonal oscillations (ISO) with a wide range of periodicities ranging from 10 days to 30-60 days (Krishnamurti, 1985, Murakami, 1983 and Lau and Chan, 1986). A number of recent studies have shown that disturbances in the short-to-intermediate time scale in the EAM and Japan can be linked to supercloud cluster formation in the warm pool of the western Pacific (Lau, 1990). On the interannual time scale, the EAM has been linked to sea surface temperature (SST) anomalies in the Kuroshio region and to the swings of the Southern Oscillation and shifts in precipitation and SST patterns in the equatorial $\mathrm{Pa}$ cific during the El Nino (Kurihara and Karahawa, 1986, Chen et al., 1989 and $\mathrm{Li}, 1990)$. In addition, a distinct atmospheric teleconnection pattern in the $500 \mathrm{mb}$ height field associated with condensational heating in the EAM region has been identified (Kurihara, 1989, Nitta, 1986, 1987, Huang, 1990). This teleconnection pattern has a significant impact on the summertime climate over Japan and East Asia and also North America (Lau and Peng, 1991).

In this paper, I shall review the above-mentioned issues concerning the EAM and identify areas where additional efforts are most needed. This review is not intended to be exhaustive in literature on the EAM, but rather be selective with in-depth discussions in areas which, in my opinion, are germane to the fundamental understanding of the EAM and its variabilities. Most of the results in this paper are based on my past and recent work on the EAM. The paper is divided in two main sections in which I review separately recent advances in observational and modeling studies of the EAM. In each section, the seasonal, intraseasonal and interannual variabilities of the EAM will be discussed in turn. The section on theory and modeling covers both results from idealized models and general circulation models (GCM). The GCM results are based partially on work sponsored by the Joint US-People's Republic of China (PRC) Monsoon Research Program as well as on the Meteorological Research Institute GCM taken from the literature.

\section{Observational studies}

\section{a. Monthly mean rainfall climatology}

The 10-year mean month-by-month variation for the extended summer monsoon season (April to September) for the period 1961-70 for 253 stations over East Asia are shown in Fig. 1. In the following, precipitation amounts of more than $200 \mathrm{~mm} / \mathrm{month}$ will be referred to as heavy rainfall. It can be seen that the heaviest rainfall is mostly confined to the south and southeastern part of the continent throughout the entire period except for July. Overall, the heaviest rainfall regions are found within a somewhat discontinuous band oriented southwest to northeast across the entire continent. In April, heavy pre-monsoon rainfall is found over Peninsular Malaysia, Borneo, central China, southern Japan and the Bay of Bengal. By May, the areas of heavy rainfall become very well defined. In the deep tropics, the region of heavy rainfall appears to have migrated northward over Vietnam and Indo-China. Enhanced rainfall is also found in the coastal region of southwestern India. The early part of June generally marks the onset of the India Monsoon and one to two weeks later, the onset of $M e i-Y u$ (or plum rain) over the Yangtze Basin in central China (Lau and $\mathrm{Li}, 1984)$. In the June map, the Mei- $Y u$ rainband appears also to be connected with heavy rain found over the East China Sea and southern Japan. In Japan, this marks the beginning of the Baiu. Because of the existence of strong frontal characteristics in the northern portion of the $M e i-Y u$ rainband, this feature is also referred to as the $M e i$ - $Y u$ front (Chen and Chang, 1980). Other regions of abundant rain are found over Bay of Bengal and Indo-China. By June, these rainy regions merge with the $M e i-Y u$ to form a somewhat continuous rain band across the southeastern part of the continent. Although there are significant differences in rainfall characteristics associated with the $\mathrm{Mei}-\mathrm{Yu}$ (over the continent) and the Baiu (over the western Pacific and Japan), in this paper we shall refer to the above rainband as the $M e i-Y u$ with the focus over the East Asian continent. ( $c f$. Ninomiya and Muraki, 1986).

In July, the rainband appears to break up. One noticeable feature is that rainfall over southern and central China $\left(25^{\circ} \mathrm{N}, 110-120^{\circ} \mathrm{E}\right)$ decreases drastically. The heavy rainfall belt over China appears to split up into two with one over northeastern China/southern Japan and one over the southwestern part of the country. At this time, the whole of the Indian subcontinent, except over southern central-India comes under the influence of heavy monsoon rain. In August, the basic rainfall pattern remains unchanged, although the rainfall amounts appear to diminish considerably. Meanwhile, there is some rainfall recovery over southern and central China. The retreat of the monsoon from the main continent can be seen from the drastic reduction in rainfall amount in September over large parts of the continent especially the northeastern corner and the central part of the country. During September, increased rainfall is noted over the Philippines, the southeast coast of China and southern Japan. This may be due to the onset of the typhoon season over these regions.

\section{b. Global scale circulation}

In this section, the seasonal variation of the global 

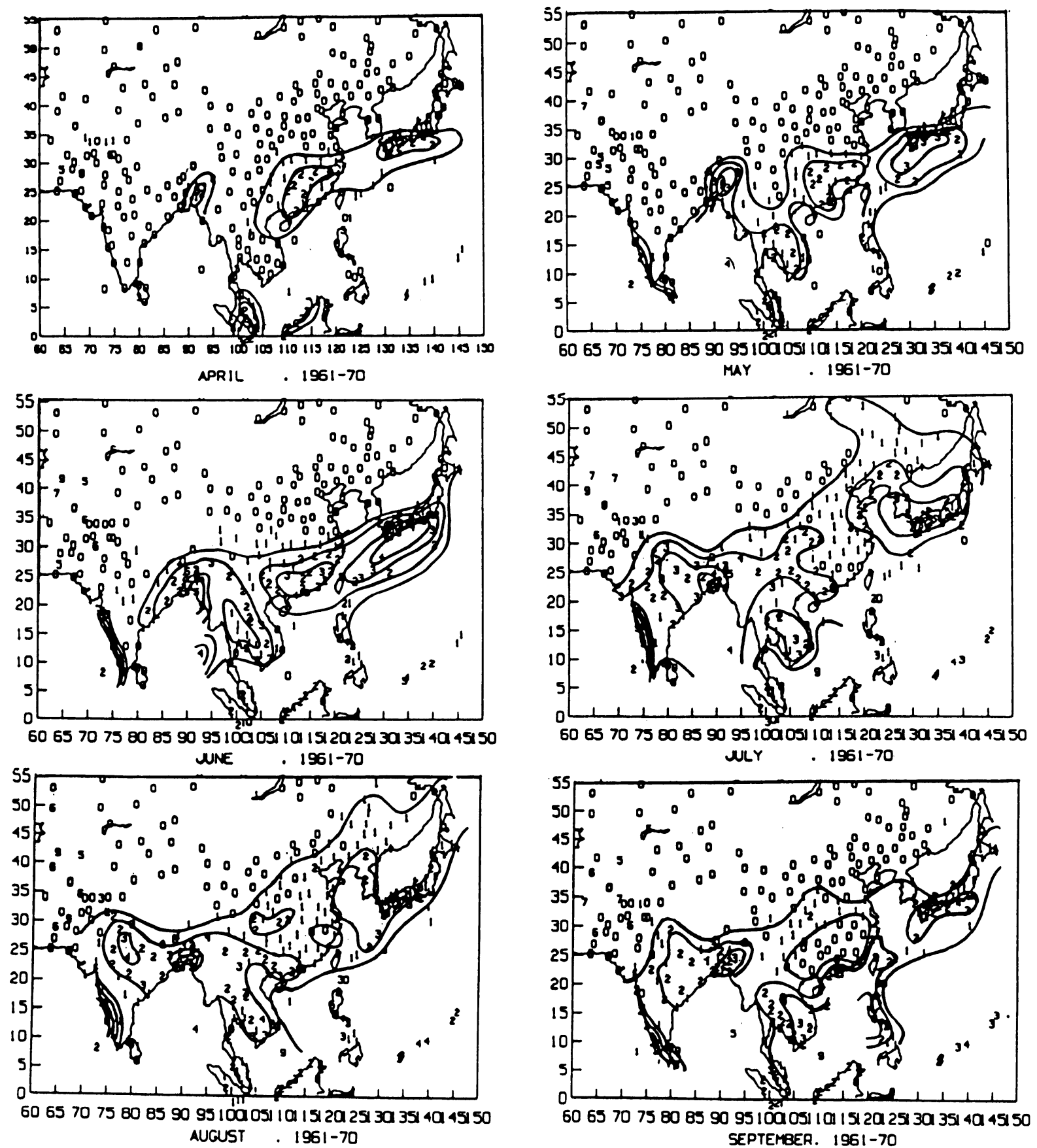

Fig. 1. Ten-year (1961-70) averaged monthly rainfall total from April to September over East Asia and India. Numerals $3,2,1$ and 0 denote rainfall totals of more than $300 \mathrm{~mm}, 200-300 \mathrm{~mm}, 100-200 \mathrm{~mm}$ and below $100 \mathrm{~mm}$ respectively.

scale circulation in relation to the EAM rainfall variability will be discussed. Figure 2 shows the climatological mean of $200 \mathrm{mb}$ streamfunction and velocity potential for June to August. The climatology is obtained from 5 years $(1978-83)$ of tropical wind data from the National Meteorological Center. The most pronounced feature in the streamfunction (upper panel) is the presence of a huge anticyclone, known as the Tibetan High during June to August.
The position of the center of the upper anticyclone as a function of the season is denoted by open and dark circles for the advance and retreat of the monsoon respectively in Fig. 2. The northwestward advance of the anticyclone center from April to August is clear. As the anticyclone center migrates northwestward, the $200 \mathrm{mb}$ westerly flow in its northern flank retreats northward and weakens while the easterly flow to the south expands and strengthens. 

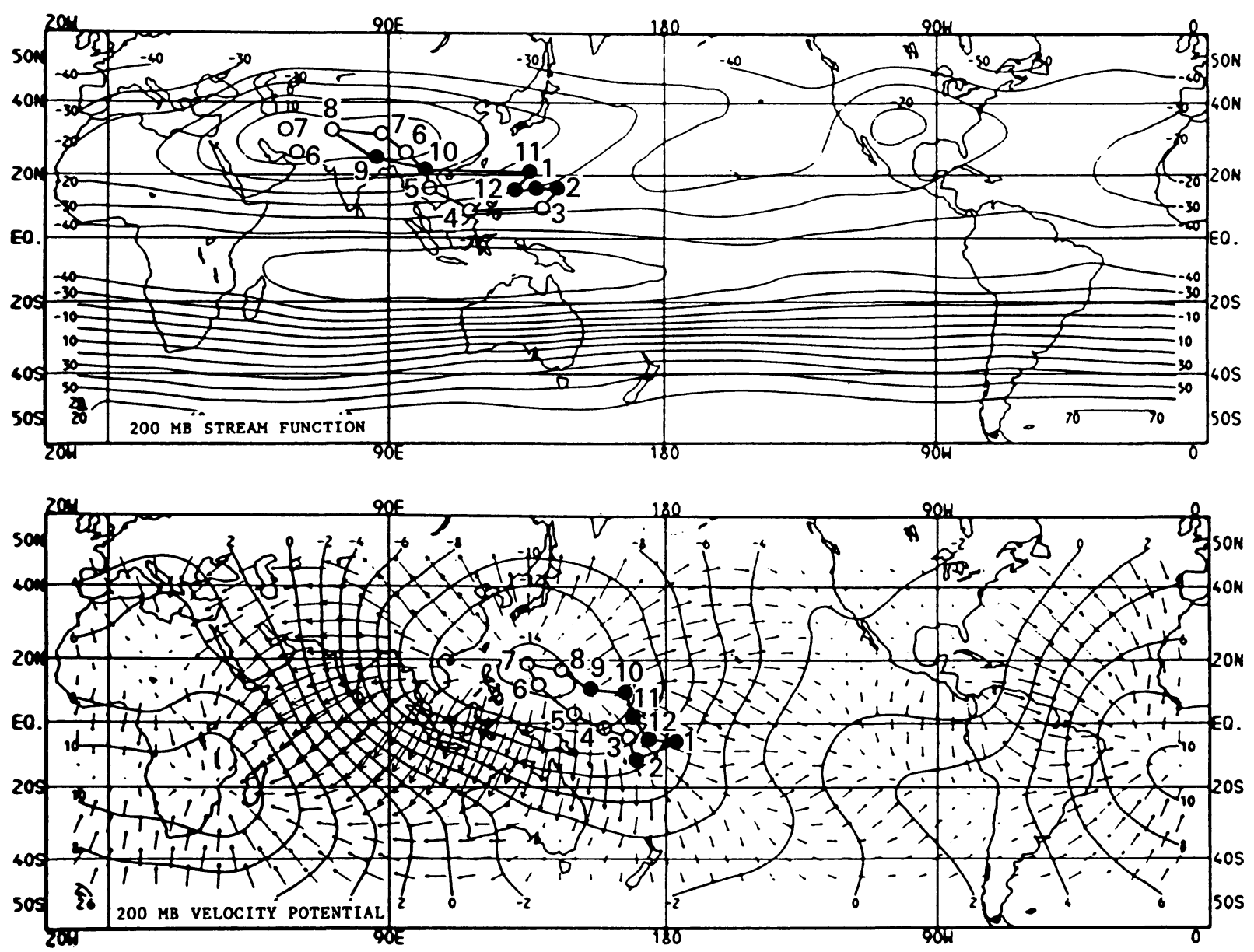

Fig. 2. Seasonal (JJA) mean $200 \mathrm{mb}$ streamfunction (upper panel) and velocity potential (lower panel). Also shown are the positions and tracks of the anticyclonic center and the divergence center of the velocity potential for different months of the year. Open (dark) circles indicate months of northern summer monsoon advance (retreat). Unit in $10^{6} \mathrm{~m}^{2} \mathrm{~s}^{-1}$.

The largest excursion of the center of the anticyclone actually occurs from March to April when the center shifts from the western Pacific to the maritime continent. The pre-monsoon rainfall occurring over Indo-China noted previously may be associated with this sudden shift in the large scale circulation. Although the seasonal mean shows that the planetary scale anticyclone stretches from western $\mathrm{Pa}$ cific to Africa, regional features can also be seen in the monthly mean. A splitting of the anticyclone center occurs when it reaches its northern extreme position in June and July. The shift of the eastern center from southwest China in June to northern Tibet in July corresponds to the time of "drying out" of the $M e i-Y u$ and the onset of monsoon rain over northern China from June to July (see Fig. 1). The wide spread heavy rain over northern India during the same period may be related to the formation of the anticyclone center further west. By August, the anticyclone centers recombine over northern Eurasia. The retreat of the anticyclone during the rest of the year is also quite noticeable with the most rapid change occurring from October to November. The movement of the center coincides with the seasonal variation of the maximum convective zone as inferred from Outgoing Longwave Radiation (OLR) field (Lau and Chan, 1983). The seasonal variation of the velocity potential (lower panel) indicates that the center of the large scale rising motion is over the western Pacific. Divergent outflow emanating from this center is strongest over India and the Arabian Sea. The advance and retreat of the center of the rising motion in the velocity potential is in concert with the migration of the anticyclone in the streamfunction field with the former located to the southeast of the latter. This displacement is consistent with the circulation pattern produced by a tropical heat source (Gill, 1980, Lau and Lim, 1982).

\section{c. Intraseasonal variation}

The following is an account of the 10-day intraseasonal climatology of rainfall over the East Asian continent based on 10 years (1961-70) of rainfall data from 253 stations over mainland China. 

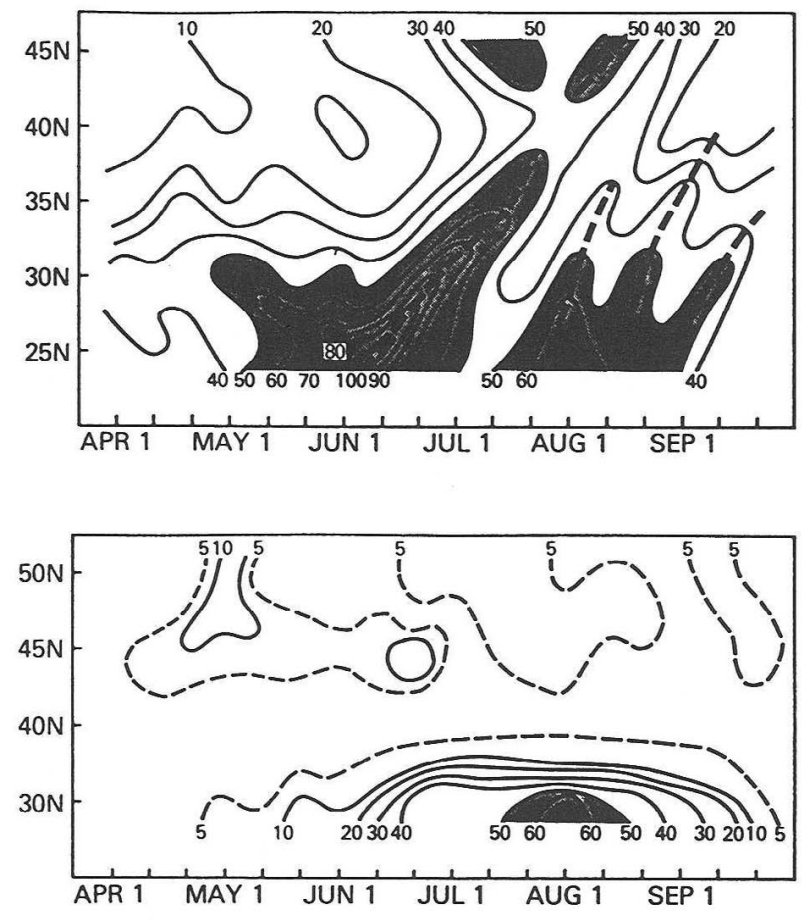

Fig. 3. (a) Time-latitude section of 10-day mean rainfall over eastern China (100$\left.115^{\circ} \mathrm{E}\right)$. Units in $\mathrm{mm}$. Regions of heavy rain $(>50 \mathrm{~mm})$ are shaded. The heavy dashed lines indicate northward propagation of the rainbelt. (b) Same as in Fig. 3a except for the western China and Tibet.

\section{(i) Latitude-time section}

As a first step to show the space/time variation of the rainband movement, latitude-time sections are constructed for stations in eastern and western China separately. The dividing longitude between the two regions is $100^{\circ} \mathrm{E}$ which separates the $\mathrm{Ti}$ betan Plateau from central and eastern China. Stations within a 5 degree latitude band centered at $25^{\circ}$, up to $45^{\circ}$ are grouped to obtain a zonal average.

Figure $3 \mathrm{a}$ shows the cross-section for eastern China. Several features are noteworthy here. The most conspicuous feature is the monsoon onset between $25^{\circ}$ to $30^{\circ} \mathrm{N}$, indicated by the steep rise in precipitation starting from the first 10-day of May (hereafter denoted by May I and other 10-day periods are similarly defined). The maximum rain found near June I to June II corresponds to the onset of the $M e i-Y u$ in central China. After the $M e i-Y u$ is fully established (June II), the rainbelt propagates northward to about latitude $40^{\circ} \mathrm{N}$, while the southern latitudes begin to dry out - a period around the first or second week of July, known as $M e i-Y u$ withdrawl in central China. The drying out of the $M e i$ $Y u$ occurs even more rapidly than the onset. Prior to July I, the northern latitudes between $40^{\circ}$ to $50^{\circ} \mathrm{N}$ are quite dry. By the end of July, heavy rain occurs abruptly near $45^{\circ} \mathrm{N}$ around July I to July II signaling the onset of monsoon rain in northern China. The rainfall diminishes somewhat for the next ten days and then revives around August I to August II. This sudden appearance of heavy rain over northern China towards the middle of July followed by recurring rainfall episodes in August is well known to native forecasters. The transition is noted for its abruptness and has been referred to as the "sudden jump" phenomenon (Li and Lo, 1983).

In the $25^{\circ} \mathrm{N}$ latitude band, the monsoon rainfall recovers around August I about 40 days after the first onset. This somewhat bimodal rainfall distribution is noticeable only in latitudes south of $30^{\circ} \mathrm{N}$. Strong subseasonal scale fluctuations with period of approximately 20 days appear to dominate the rainfall variation between $25^{\circ}$ and $40^{\circ} \mathrm{N}$ for the remaining part of the season from the latter part of July to the end of September. This 20-day fluctuations appear to originate around $25^{\circ} \mathrm{N}$ and propagate northward to $40^{\circ} \mathrm{N}$. Examination of the above features for every year shows that, in spite of large interannual variability, they arc remarkably consistent and identifiable almost every year. These results suggest that the quasi-20 day cycle is phase-locked to the seasonal cycle. Further studies using independent data with longer records are required to confirm this.

A similar latitude-time section is constructed for western China including Tibet (Fig. 3b). Here a much simpler picture emerges. Compared to the east, the monsoon rainfall is notably weaker although the rainfall season is quite well defined around $30^{\circ} \mathrm{N}$. The heavy monsoon rain (>50 mm/10 days) comes late in the season around July III and lasts only briefly for a little longer than a month without break. There is a persistent rainfall minimum around $40^{\circ} \mathrm{N}$. Further north, rainfall appears to be sporadic and not very well organized.

The dramatic difference in rainfall regime in eastern and western China can be understood in terms of the large topographical influence on the regional circulation. This is illustrated in Figs. $4 \mathrm{a}$ and $4 \mathrm{~b}$ which show the meridional circulation along $115^{\circ}$ and $90^{\circ} \mathrm{E}$ respectively based on wind analysis from the Institute of Atmospheric Physics, China. During April, the vertical circulation at $115^{\circ} \mathrm{E}$ consists of two cells, one with rising motion near the equator and one over central China. The former may be associated with the rainfall and convective activity over Peninsular Malaysia noted in Fig. 1. The actual wind magnitude (not shown) indicates that the ascent over the main continent is relatively weak at this time. The weak rising motion may be related to the confluence between the weak polar front and the pre-monsoon northerly flow at the surface. By May, the monsoon Hadley-type circulation developes into a single cell with rising motion over the central part 

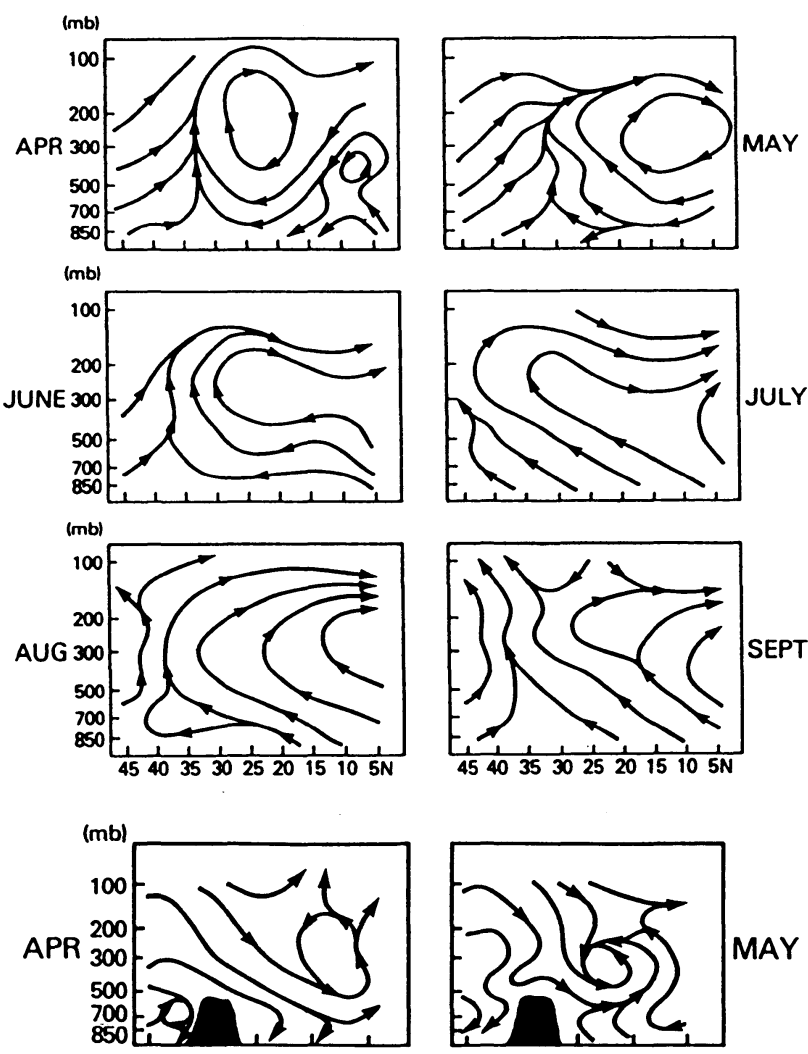

MAY
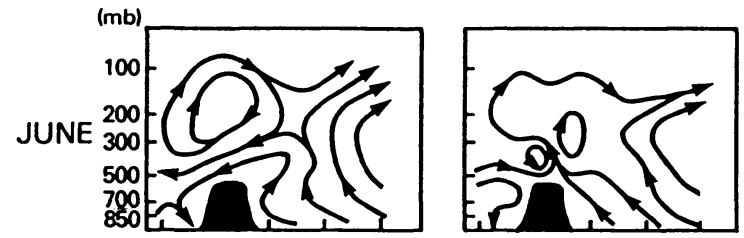

JULY
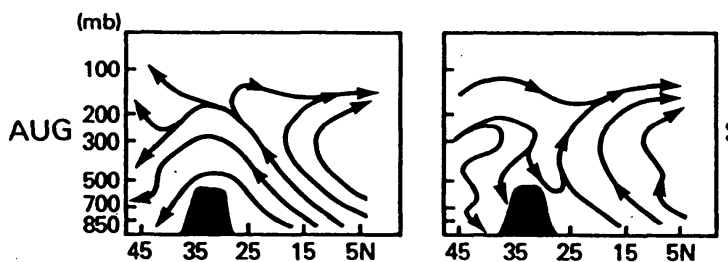

SEPT

Fig. 4. Latitude height cross section of monthly streamlines in the meridional plane from April to September for (a) $115^{\circ} \mathrm{E}$ and (b) $90^{\circ} \mathrm{E}$.

of China and sinking motion to the south. This Hadley-type circulation amplifies and maintains itself through June to August. Also noticed is the northward migration of the low level convergence zone from central to northern China from May to August. By September, the vertical cell weakens and breaks up with the low level convergence zone shifting to southern China signaling the retreat of the monsoon.

As a contrast to the above, at $90^{\circ} \mathrm{E}$ a deep monsoon Hadley-type circulation south of the plateau is not well-developed until June. In July, a double cell appears to develop over the top of the plateau. This is probably due to the effect of sensible heat flux from the top of the plateau acting as an elevated heat source (Luo and Yanai, 1983). The low level moist inflow from the Bay of Bengal from June to August is most likely to be responsible for the onset of monsoon rainfall on the southward facing slope of the Tibetan Plateau. The diminished monsoon observed here is probably due to the depletion of moisture as the low level monsoon flow climbs the southern slope of the Himalayas. On the other hand, the northern slope near $40^{\circ} \mathrm{N}$ is constantly under the large scale subsidence on the lee side of the monsoon current and is therefore cut off from any monsoon influence from the south. The sporadic rainfall variation noted around $40-50^{\circ} \mathrm{N}$ is likely to have a polar origin and not directly related to the EAM.

\section{(ii) Rainfall regimes and transitions}

In order to focus on the transition between different rainfall regimes, difference maps between a 10-day mean and its preceding 10-day mean are constructed. The maps for the period from May III to August I are shown in Figs. 5a-5h. In general, rainfall patterns show alternating positive and negative or wavetrain-like patterns in the north-south direction. These patterns generally suggest a northward propagation interspersed with east-west expansion and contractions of the major rainband.

Beginning in May III (Fig. 5a), the pattern shows enhanced rainfall relative to the previous period in the southernmost and southwestern part of China and a broad region of reducing rainfall in central China. This pattern fluctuates somewhat irregularly between June I to June II, but with increased rainfall confined to the southern part of the country. Between June II to June III, a well-organized zonally oriented rainband is established from the coast to $100^{\circ} \mathrm{E}$ over central China (Fig. 5d). This corresponds to the $\mathrm{Mei}$ - $\mathrm{Yu}$ onset in the Yangtze Basin in central China. At this time southern China (south of $30^{\circ} \mathrm{N}$ ) experiences relatively dry condition.

The next ten-day period (Fig. 5e) indicates a drying out of the Mei-Yu and the establishment of new rain centers in northern and southern China. The withdrawal of the $M e i-Y u$ is completed by July II (Fig. 5f). A new rainfall maximum is established in the northeast and a new rainband begins to emerge from the extreme south. The distribution of the rainfall pattern appears to be $180^{\circ}$ out of phase with that during the onset phase (Fig. 5d) with central China experiencing relatively dry conditions. The emerging rainband from the deep south progresses northward while the dry belt over central China shrinks (Fig. 5g). The dry condition during the latter part of July is commonly dreaded experience for the populace of central China because of the extremely high temperature and drought-like condition occurring during this period (Lin, 1985). This period lasts for about 20 days before the rainy sea- 

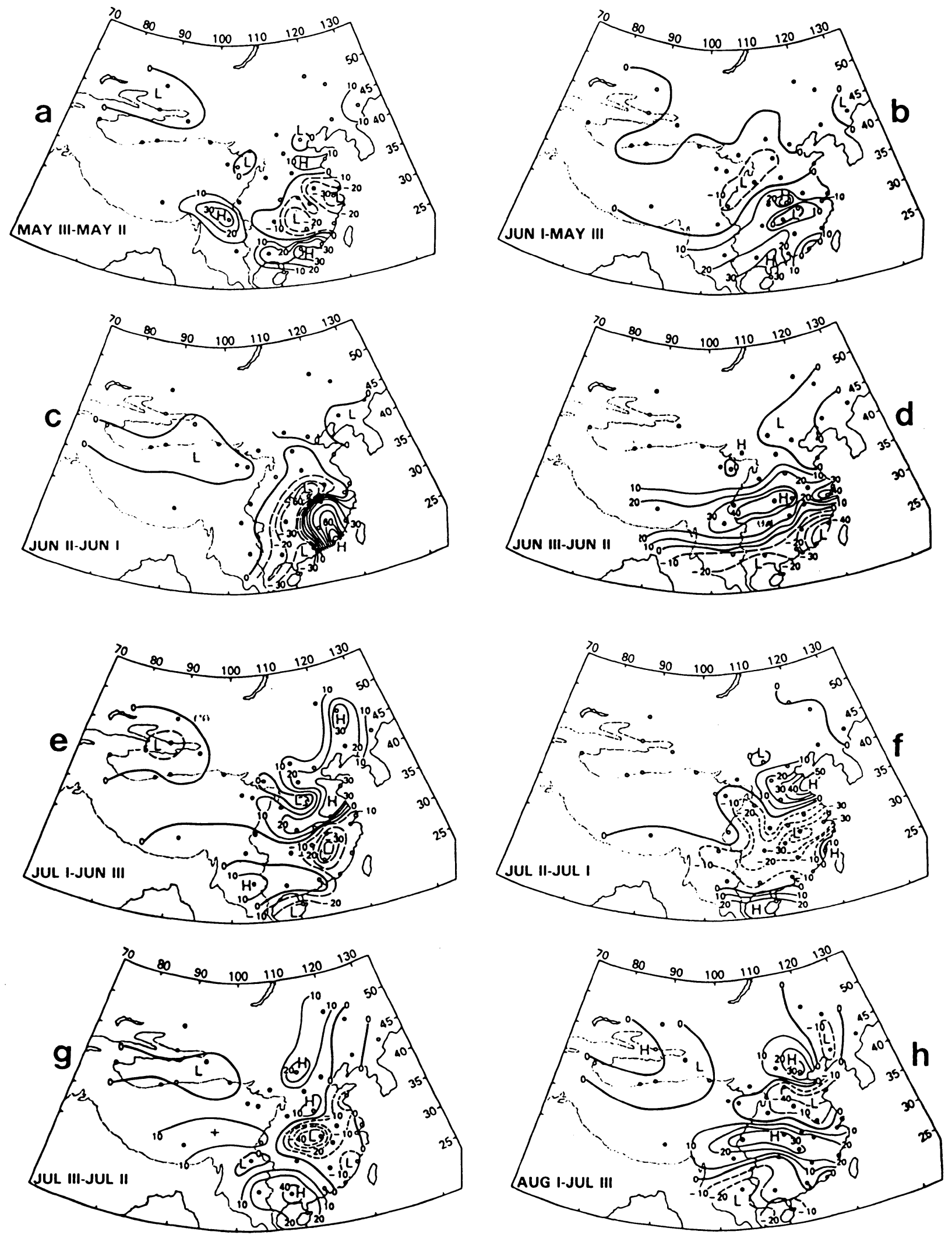

Fig. 5. Difference maps of 10-day mean rainfall during different phases of the summer monsoon over East Asia. See text for detailed explanation. Unit in $\mathrm{mm}$. 
son resumes. By August I, a major rainband is again formed over the Yangtze Basin (Fig. 5h). This second peak in rainfall in this region occurs about 40 to 50 days after the $M e i-Y u$ onset. At this time the wavetrain pattern over the entire eastern portion of the country, stretching from south to north is quite evident (Fig. 5h). From hereon, the whole eastern China enters an "oscillatory rainfall regime" with a period of the order of 20 days. The oscillation is most pronounced between $25^{\circ}$ to $40^{\circ} \mathrm{N}$. From August to September, wavetrain patterns similar to Fig. 5h, but with different spatial phases, continue to dominate the rainfall variation. It is also noted during the period from August to September, the meridional scale of the rainband is smaller than the onset and pre-onset periods. This may be related to the faster time scale associated with the 20-day fluctuations noted previously.

\section{(iii) Zonal wind variations}

The transition into the $M e i-Y u$ regime (early to middle June) is characterized by a rapid northward migration of the subtropical high accompanied by a corresponding shift in the upper level westerlies over eastern China and Japan. Figure 6 shows the vertical section of the 5-day mean zonal wind in at $125^{\circ} \mathrm{E}$ during a typical transition. Before May 11-15, the upper level westerly jet is located at $35^{\circ} \mathrm{N}$ and the center of the easterlies at $15^{\circ} \mathrm{N}$. At this time the axis of the upper level anticyclone (approximately coincides with the zero zonal wind line in Fig. 6) is at $20^{\circ} \mathrm{N}$. The northward shift of the upper level jet occurs rapidly in 5 to 10 days in the beginning of June after which the westerly core is located over a stationary position near $40^{\circ} \mathrm{N}$ and the axis of the anticyclone near $25^{\circ} \mathrm{N}$. This transition is also accompanied by a northward penetration of low level westerlies to the foothills of the Himalayas in southwestern China (not shown). At the end of July, a second northward transition occurs with the westerly jet further shifted to $45^{\circ} \mathrm{N}$ in a similar manner giving rise to the monsoon onset over north and northeastern China (Lau et al., 1988). The movement of the monsoon rainband appears to jump between stationary positions from low to high latitudes. The abruptness of the transition and the large extent of the area affected by the monsoon rainfall are unique features of the EAM rainfall that do not have a counterpart in the India region.

\section{(iv) Inter-monsoon relationships}

The relationship between the Indian and the EAM are discussed in this section. Empirical orthogonal function analysis is applied to 5-day mean outgoing longwave radiation (OLR) anomaly data. The seasonal cycle and long term variations have been removed by a 5 to 90 day band-passed filter to emphasize the intraseasonal time scale. The OLR is used as proxy for rainfall over the monsoon regions

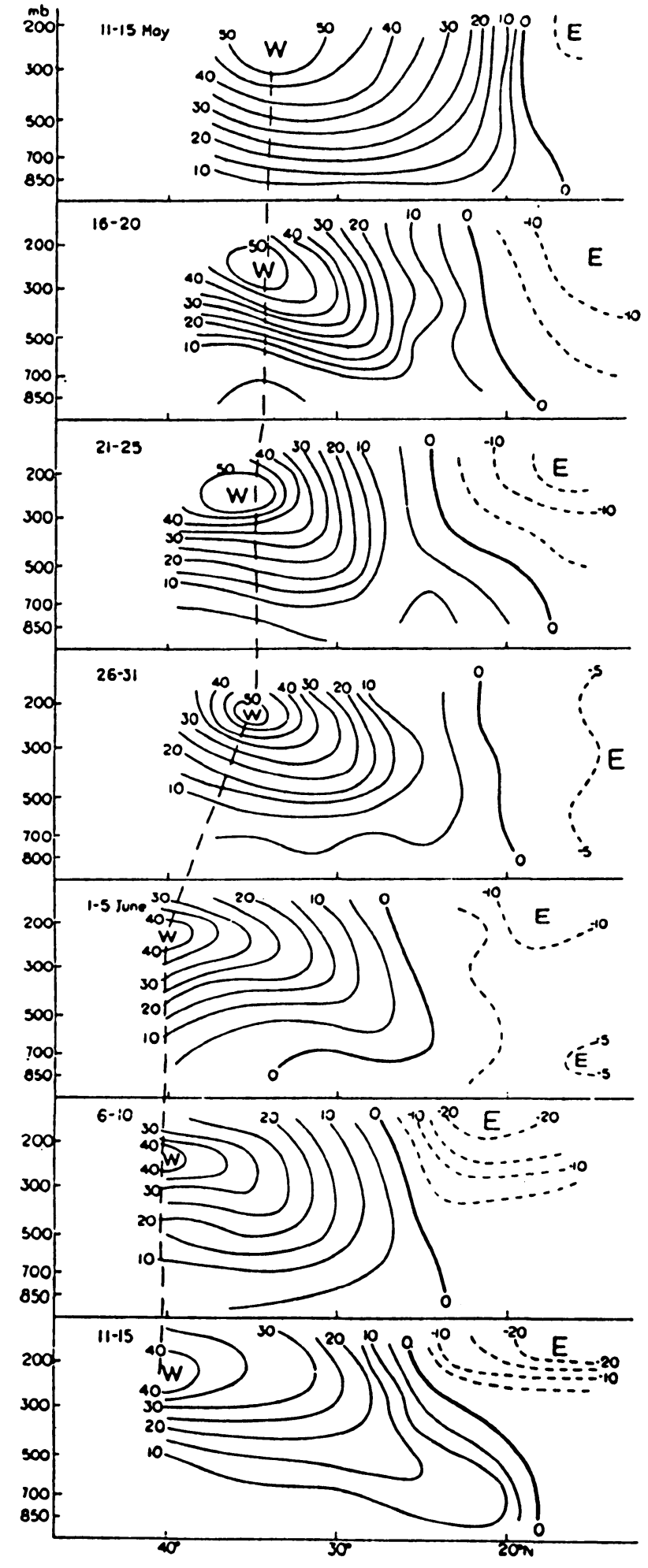

Fig. 6. Five-day mean cross-section of zonal wind along $125^{\circ} \mathrm{E}$ over the east China Sea from May to June, showing the typical abrupt northward shift of the upper level westerlies. Unit is $\mathrm{m} / \mathrm{s}$.

and the adjacent oceans. Figure 7 (upper panel) shows the EOF1 structure of OLR. The most dominant feature is an eastwest oriented dipole with cen- 

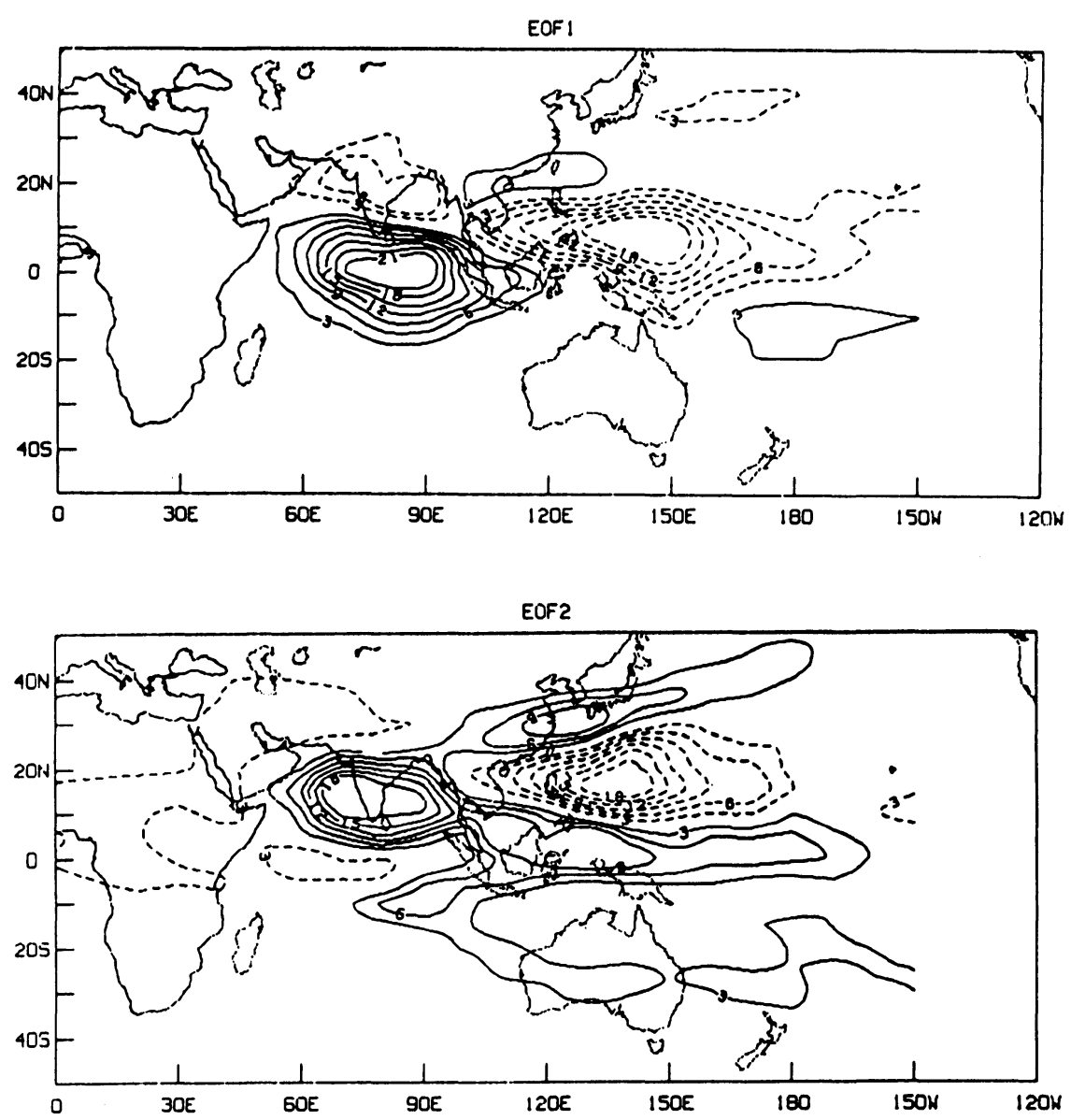

Fig. 7. Spatial structures of the first (upper panel) and second (lower panel) EOF of 5-day mean OLR over the greater EAM region including India. The contour values are in relative units with interval of 3. Negative contours are dashed and zero contours are suppressed.

ters over the Indian Ocean and the western Pacific. The anomaly over the Indian Ocean stretches form the Arabian Sea to the maritime continent along the equator, while the anomaly over the western Pacific extends form Indo-China into the equatorial western Pacific. North of the equatorial dipole, there is a much weaker secondary dipole of opposite polarity located over the Indian subcontinent and the South China Sea. In EOF2 (Fig. 7 (lower panel)), the centers of the east-west dipole are displaced northward to $15^{\circ} \mathrm{N}$ over the Indian subcontinent and an area just east of the Philippines. The Indian anomaly extends eastward into the western and central Pacific along the equator, forming a very well-defined near-equatorial ITCZ. A distinct band of positive anomaly also appears to stretch from India through southwest and central China and Japan into the northwestern Pacific. This may be identified with the $M e i-Y u$ rainband. The positive anomalies comprising those over India, the western Pacific ITCZ and the narrow band over China and Japan appear to form an elongated horse-shoe pattern surrounding the strong negative center over the South China Sea and Philippines.
The evolution of the above pattern can also be described in terms of extended EOFs (EEOF, $c f$. Lau and Chan, 1986). Figure 8 shows the sequence of OLR pattern at interval of 5 days. The arrows indicate the displacement of the centers in 5 days and the dark circles indicate a stationary center. At Day 0 of EEOF2, the east-west dipole is fully developed. The center over the Indian Ocean simultaneously shifts northward and extends eastward into the equatorial western and central Pacific at a rate of about one degree latitude per day and five degree longitude per day respectively while the anomaly over the western Pacific shifts northwestward. At Day 5 , the dipole splits into a quadruple pattern, as the original dipole continues to shift northward and new anomalies of the opposite sign are generated near the equator. This should be compared to the EOF2 pattern in Fig. 7 (lower panel). The equatorial dipole propagates predominantly eastward along the near-equatorial trough over the Indian Ocean and the western Pacific. By Day 10, the northern dipole appears to become stationary and weak, but the southern dipole begins to intensify, with the western Pacific anomaly moving northwestward. 

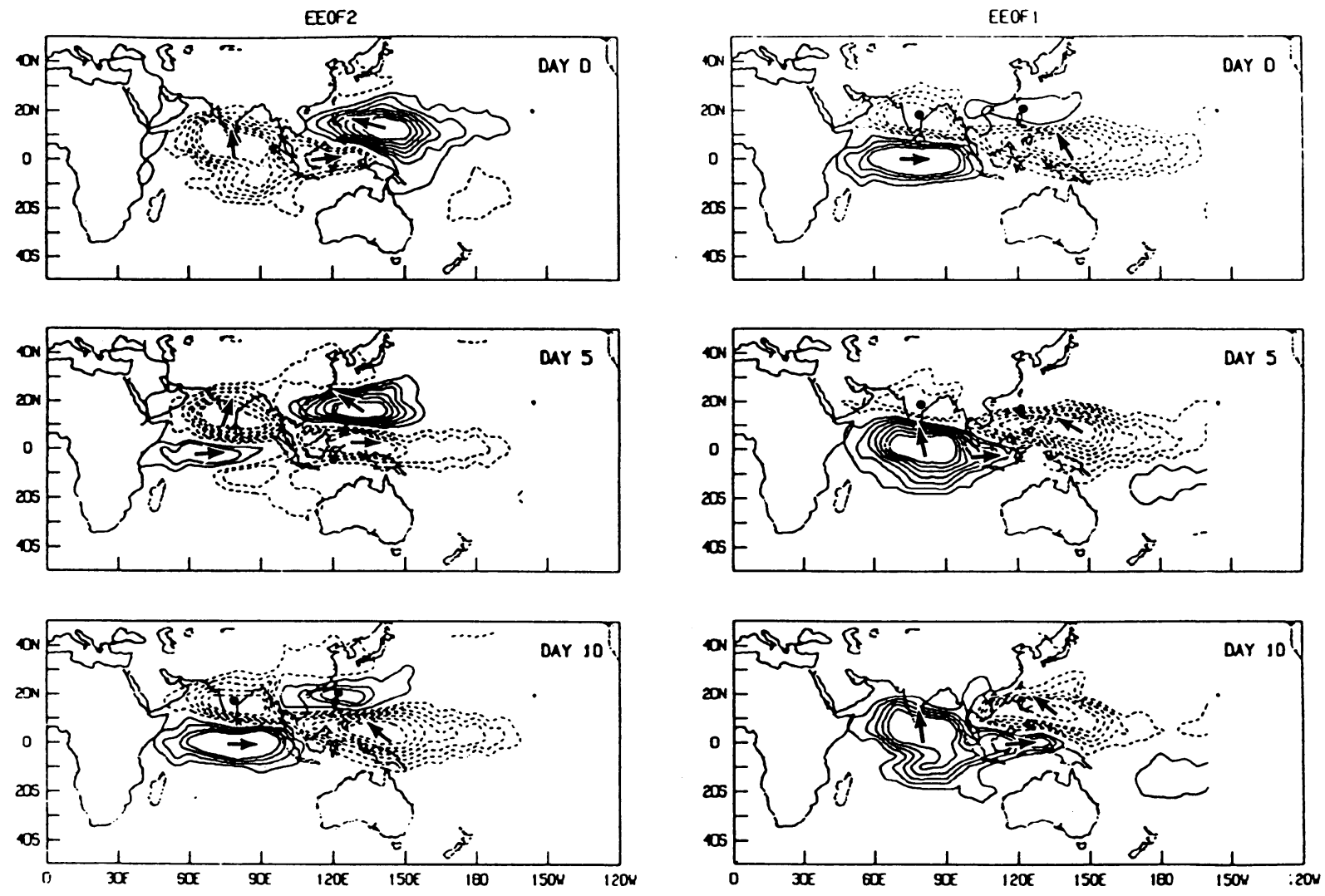

Fig. 8. Space-time structure of the first and second EEOF of 5-day mean OLR over the monsoon region. Unit as in Fig. 7.

This situation continues at Day 0 of EEOF1. By Day 5 and Day 10 of EEOF1, the northern dipole vanishes over the foothills of the Himalayas and central China while the southern dipole steadily shifts northward. Near the equator, the Indian Ocean anomaly continues to expand eastward. The pattern at Day 10 of EEOF1 is almost an exact mirror image of that at Day 0 of EEOF2 indicating a halfperiod of about 20 days.

\section{(v) Seasonal modulation}

A closer look at the 30-60 day oscillation and its relationship with the seasonal variation of tropical convection is presented in the following. Figure 9 shows the amplitude and phase of the OLR seasonal cycle (annual first harmonic) at each grid point in the form of a dial pointing to the time of minimum OLR (maximum convection). The phase of the dial follows that of a time clock, i.e., 1 December is indicated by a stick pointing northward. The length of the dial is proportional to the amplitude of the first harmonic. Grid points in which the variance of OLR in the 30-60 day band exceeds $12 \%$ (18 $\%$ ) of the total variance for the northern (southern) hemisphere summer are denoted by crosses (open circles). The summer monsoon region is characterized by relatively long sticks pointing in the 7 to 8 o'clock position (July-August). This includes a

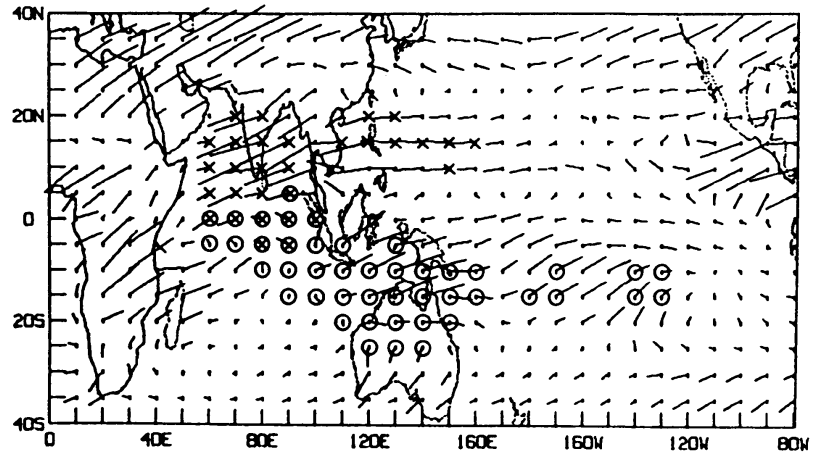

Fig. 9. Phase and amplitude of the seasonal cycle of 5-day mean OLR. The length of each stick is proportional to the amplitude of the seasonal cycle at each grid point (see text for details). Open circles and crosses indicate maximum 30-60 day variance of greater than $18 \%$ of the total for the winter and $12 \%$ for the summer respectively.

large area stretching from the Arabian Sea, across the Indian Ocean to the western Pacific. Likewise, the winter monsoon region is indicated by sticks pointing in the 1-2 o'clock position (January to February). This include the maritime continent and the western and central Pacific between the equator and $20^{\circ} \mathrm{S}$. A second winter monsoon region is 
located over central and eastern Africa near Madagascar. The area of large 30-60 day variance appear to coincide with the region of maximum monsoon activity, suggesting a close link between the features. Most interesting to note is that there is a region over the equatorial Indian Ocean $\left(60-100^{\circ} \mathrm{E}\right)$ where large 30-60 day variance is found in both the monsoon seasons. In this region, the propagation of the 30-60 day wave is pronounced throughout the year. Theoretical studies suggest that the 30-60 day oscillations are manifestation of intrinsic equatorial wave modes arising from interaction between convection and circulation (Lau and Peng, 1987). These modes are strongly modulated over the Indian Ocean, East Asia and northern Australia by interaction with the monsoon circulation over these regions. It has been suggested that the 30-60 day oscillation and other higher frequency atmospheric fluctuations may provide stochastic forcings necessary for triggering ENSO (Lau and Chan, 1986, 1988 and Lau and Shen, 1988). Such triggering is generally favored by the relatively high sea surface temperature over the Indian Ocean and the Western Pacific during northern winter.

\section{d. Interannual variations}

\section{(i) Principal modes of rainfall variations}

Figure 10 shows the first EOF eigenvector and principal component of rainfall total from April to September based on 30 years of 5-day mean rainfall data over mainland China. This EOF explains 17.5 $\%$ of the total interannual variance and shows large signal over central and eastern China with maximum variability centered along $30^{\circ} \mathrm{N}$. The time coefficient indicates a strong quasi-biennial signal. The biennial tendency is particularly pronounced after 1973 . Before 1973, the time series shows mostly negative values indicating a prolonged deficit of rainfall over central China. The time series peaks during the second calendar year of major ENSO (1969, 1973, 1977 and 1983). This suggests that summertime flood in central China is likely to follow a warmer-thannormal SST in the eastern Pacific during the preceding winter. Yet, the drought/flood conditions also seem to alternate with a biennial time scale that may be independent of the major ENSO occurrences. The second rainfall EOF, which explains $13.7 \%$ of the total interannual variance, depicts a north-south seesaw variation with the zero line running approximately along $30^{\circ} \mathrm{N}$ and with larger contribution from southern China (not shown). The time coefficient of this mode exhibits a quasi-biennial variation as the first EOF, but it appears to have little relationship with ENSO. The above results suggest that the rainfall over mainland China possesses its own internal variability while at the same time may be linked to the ENSO and a tropospheric quasibiennial oscillation. The source of this biennial os- cillation is unknown. It may be related to a similar biennial oscillation found over the Indian monsoon region (Yasunari, 1990). Most likely the interaction between atmosphere and sea surface temperature (SST) and/or land surface processes play major roles. The relationship between SST and EAM is considered next.

\section{(ii) Relationship with $S S T$}

Figure 11 shown the lagged correlation patterns of the EOF1 of East Asian rainfall with the SST anomaly everywhere within the $30^{\circ} \mathrm{N}$ and $30^{\circ} \mathrm{S}$. For convenience, the following discussion is relative to a positive rainfall anomaly over East Asia. During the preceding winter (DJF), a dipole SST pattern is found with warm water over the Kuroshio off the coast of East China and cold water over the equatorial western Pacific west of the Philippines. The correlation between SST and EAM rainfall is significantly positive $(>0.4)$ over the equatorial eastern Indian ocean and the equatorial eastern Pacific. The entire Indian and Pacific basin generally show warmer than normal SST. The dipole SST pattern becomes much more enhanced especially in the warm SST region immediately off the coast of East China. By MAM, the warm water in the Indian Ocean has shifted into the northern Australia and maritime continent while that in the eastern Pacific has weakened considerably. At the time of the increased EAM rainfall (JJA), the warm SST near East China expands into the South China Sea and merges with warm water around Australia. At this time, the warm water region is most extensive and well defined over the sector between $90^{\circ} \mathrm{E}$ to the dateline while the anomaly over the eastern $\mathrm{Pa}$ cific has all but disappeared. As a result, the SST pattern is characterized by an east-west seesaw between the Indian Ocean/maritime continent and the central and eastern Pacific. In the SON season that follows, the warm water in the Indian Ocean and the western Pacific migrates eastward and the cold water over the tropical eastern and central pacific becomes increasingly well developed. By the following winter, the entire SST pattern has almost turn around from the previous winter, with below normal SST in the Indian Ocean and the eastern Pacific. The subtropical western SST dipole now features cold water off the coast of East China and warm water to the south. In the southern hemisphere, SST is abnormally high in the region of the SPCZ.

The seesaw of SST in the equatorial region can be seen clearly in Fig. 12 which shows the lagged correlation between the monsoon rainfall and the SST over the western Pacific $\left(5^{\circ} \mathrm{N}-5^{\circ} \mathrm{S}, 120-150^{\circ} \mathrm{E}\right)$, central $\left(5^{\circ} \mathrm{N}-5^{\circ} \mathrm{S}, 160^{\circ} \mathrm{E}-160^{\circ} \mathrm{W}\right)$ and eastern Pacific $\left(5^{\circ} \mathrm{N}-5^{\circ} \mathrm{S}, 90^{\circ} \mathrm{W}-120^{\circ} \mathrm{W}\right)$ respectively. In the central and eastern Pacific, the correlation goes from a 


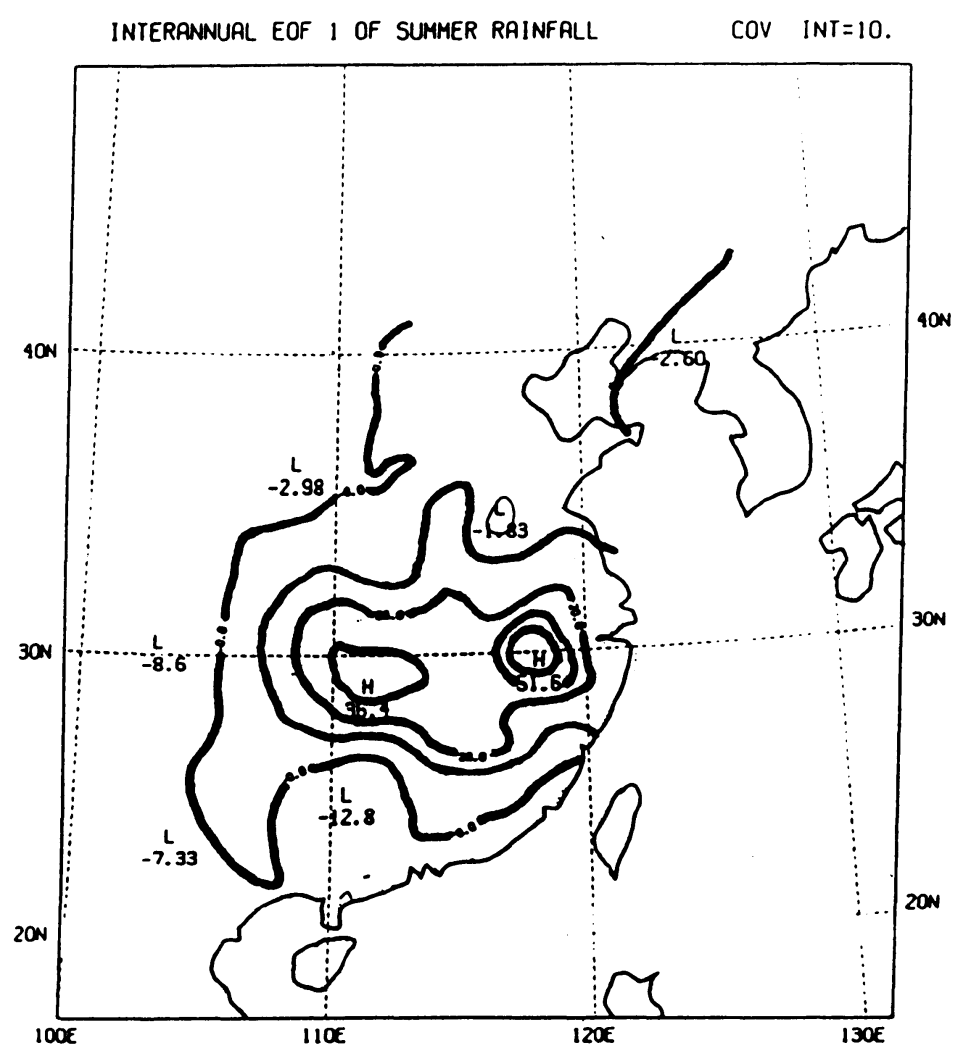

INTERANMUR EOF I OF SUMER RAINFALL COV

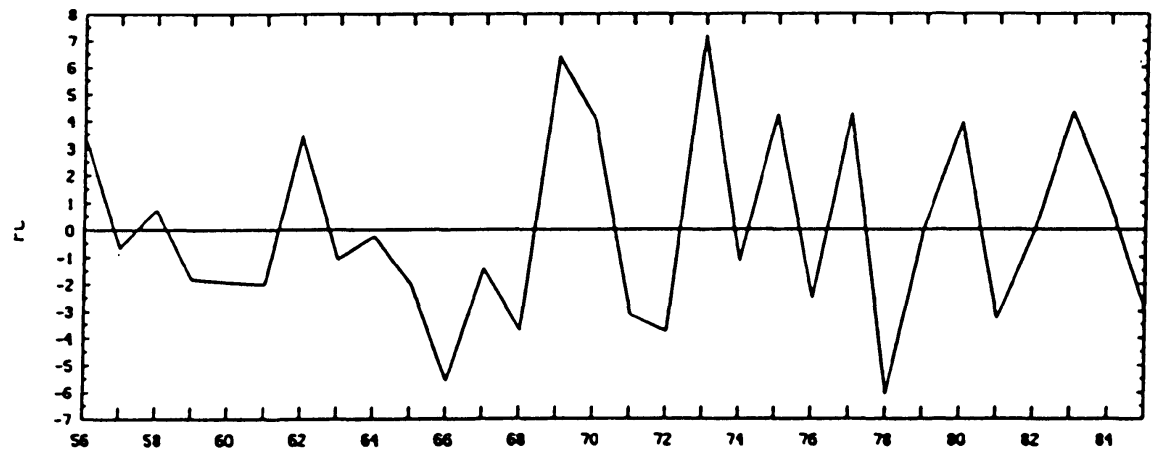

Fig. 10. (a) First EOF pattern of rainfall over East Asia based on 30 years of rainfall total from April to September in relative units. (b) Principal component associated with first EOF in relative units.

positive maximum in the preceding fall and winter (September to February) to negative maximum in the following fall and winter. However, the correlation with the preceding spring is close to zero. In the equatorial western Pacific, the pre-monsoon SST signal is weak, but the post-monsoon signal is remarkably strong and varies inversely with those in the central and eastern Pacific. The above correlations suggest that the EAM is about $90^{\circ}$ (approximately 6 months) out of phase with a quasi-biennial signal in SST. The resemblance of the SST correlation map with that of the dominant ENSO SST pattern ( $c f$. Rasmusson and Carpenter, 1982) con- notes a relationship between EAM and ENSO. The phase relationship further suggests that the EAM is not a passive respondent to the SST anomalies in the equatorial regions but rather an active driver of the entire biennial/ENSO global oscillation ( $c f$. Yasunari, 1988 and 1990).

(iii) Relationship with surface wind

Figure 13 shows the lag correlation of the first principal mode of rainfall with the surface wind over the global tropics. The surface wind is based on the COADS dataset. The correlation has been multiplied with the standard deviation of the wind 


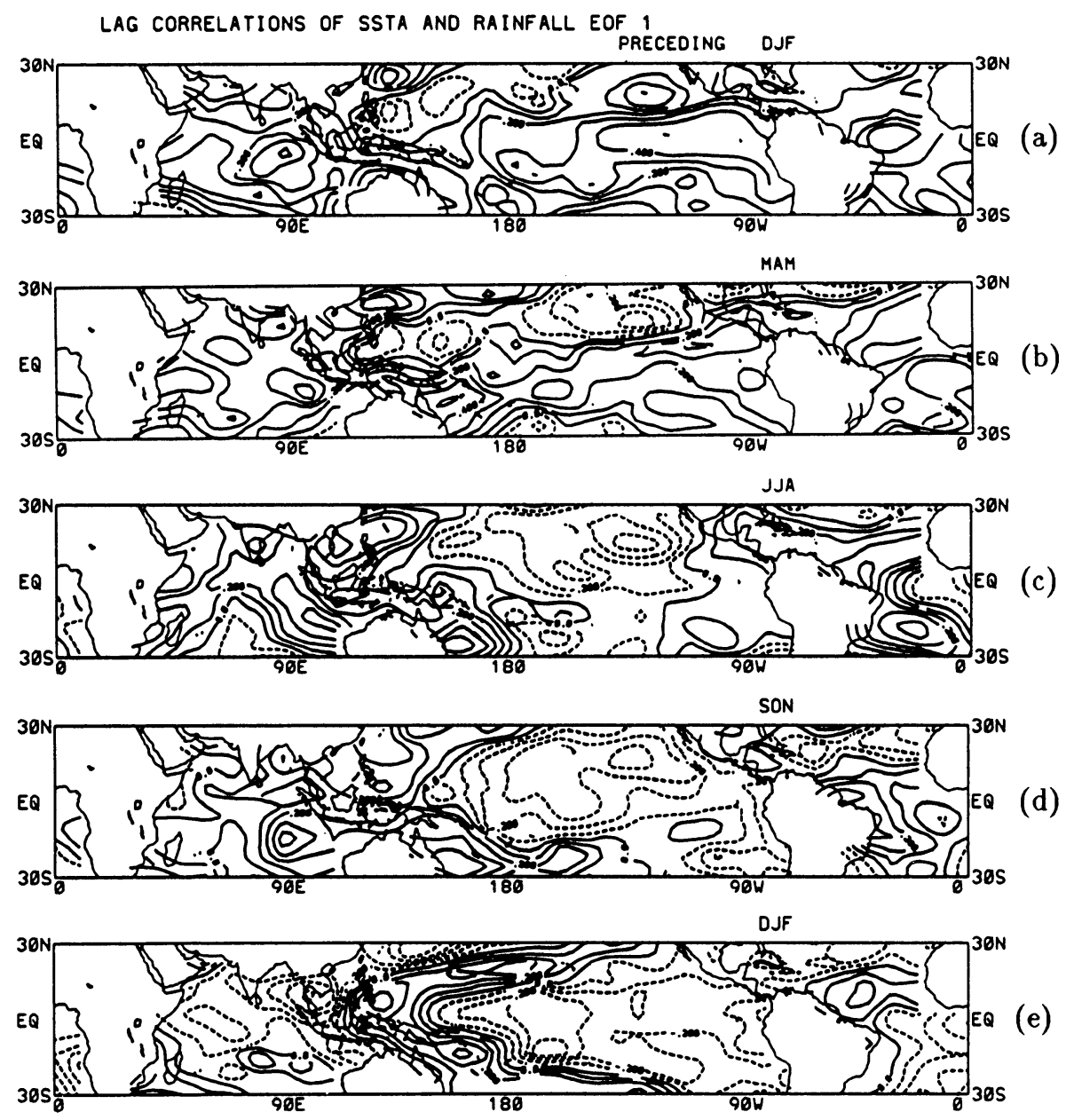

Fig. 11. Lag correlation pattern of seasonal mean SST and first principal component of EAM rainfall showing evolution of SST anomalies in relation to above-normal EAM rainfall.

field, so that the magnitude of the correlation vector is a measure of the magnitude and direction of the wind vector. For convenience, we shall refer to the correlation wind vectors as wind vectors in the following discussion. During the winter (DJF) preceding an above normal monsoon in East Asia, surface easterlies are found over the equatorial Indian Ocean where the SST is above normal (see Fig. 11a). Surface westerlies are found over the equatorial central Pacific. Over the maritime continent surface wind divergence prevails, indicating subsidence motion associated with reduced convection over the region. There is strong meridional wind convergence along the equator in the warm water region of the eastern Pacific (see Fig. 11a). Along the coast of East Asia and the South China Sea, the anomalous flow is poleward towards the subtropical warm pool in the region of the Kuroshio (Fig. 11a). This is in opposite direction to the climatological northeasterlies, indicating a weakening of the winter monsoon (Chang and Lau, 1980 and Lau et al., 1983). The spring season (MAM) preceding heavy rainfall in East Asia is characterized by strong surface easterlies over the equatorial western Pacific and strong meridional convergence of surface wind over the equatorial central Pacific. Over the subtropical western Pacific, and anticyclonic circulation can be found. This anticyclonic circulation will be instrumental in supplying low level moisture into the EAM region. The large scale surface flow is generally consistent with divergent flow over the cold water and convergent flow over the warm water. By JJA, the easterly band over the maritime continent shifts northward and becomes very well established while expanding eastward to $160^{\circ} \mathrm{W}$ and westward into the Bay of Bengal. The anticyclonic flow off the southeastern coast of China remains strong, indicating a continuing advection of warm moist air from the subtropical western Pacific into East Asia. The large scale changes in surface wind are apparently in concert with the development of the cold SST anomaly over the central Pacific and the development of the SST anomaly seesaw between the eastern and the western part of the ocean basin noted in the discussion of Figs. 11 and 12. Strong surface easterlies persist in the western Pacific into 
CORRELATION BETWEEN RAINFALL RND SST

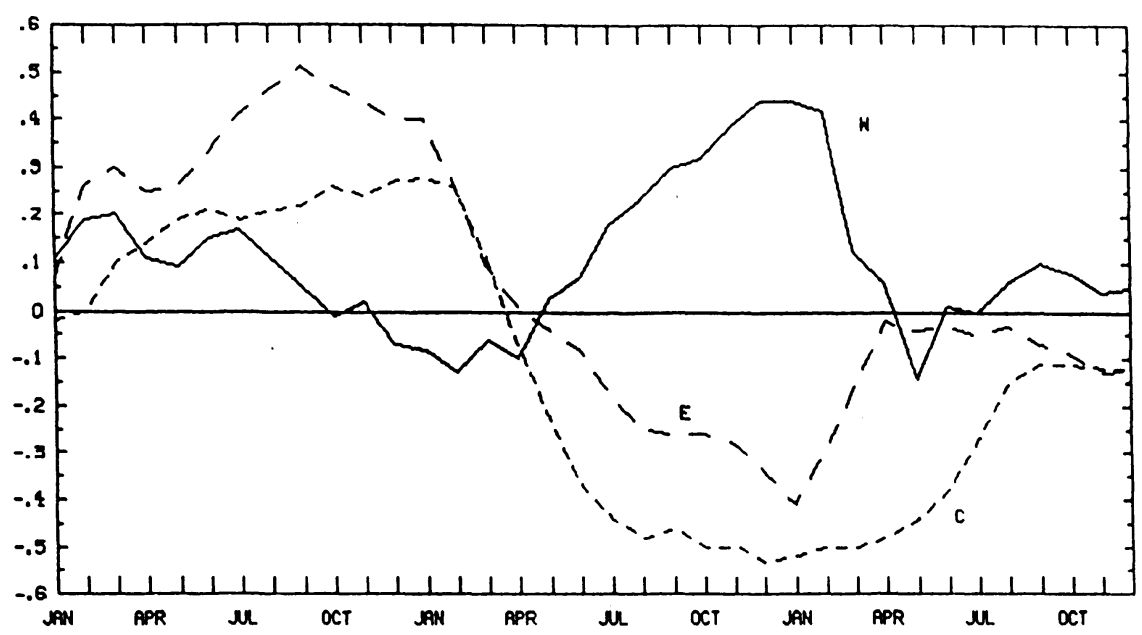

Fig. 12. Lag correlation coefficient of first component of EAM rainfall with area-averaged 3-month running mean SST over the western Pacific $\left(5^{\circ} \mathrm{N}-5^{\circ} \mathrm{S}, 120^{\circ} \mathrm{E}-150^{\circ} \mathrm{E}\right)$, the eastern Pacific $\left(5^{\circ} \mathrm{S}-5^{\circ} \mathrm{N}, 90^{\circ} \mathrm{W}-\right.$ $\left.120^{\circ} \mathrm{W}\right)$ and the central Pacific $\left(5^{\circ} \mathrm{S}-5^{\circ} \mathrm{N}, 160^{\circ} \mathrm{E}-160^{\circ} \mathrm{W}\right)$ as a function of the calendar month.

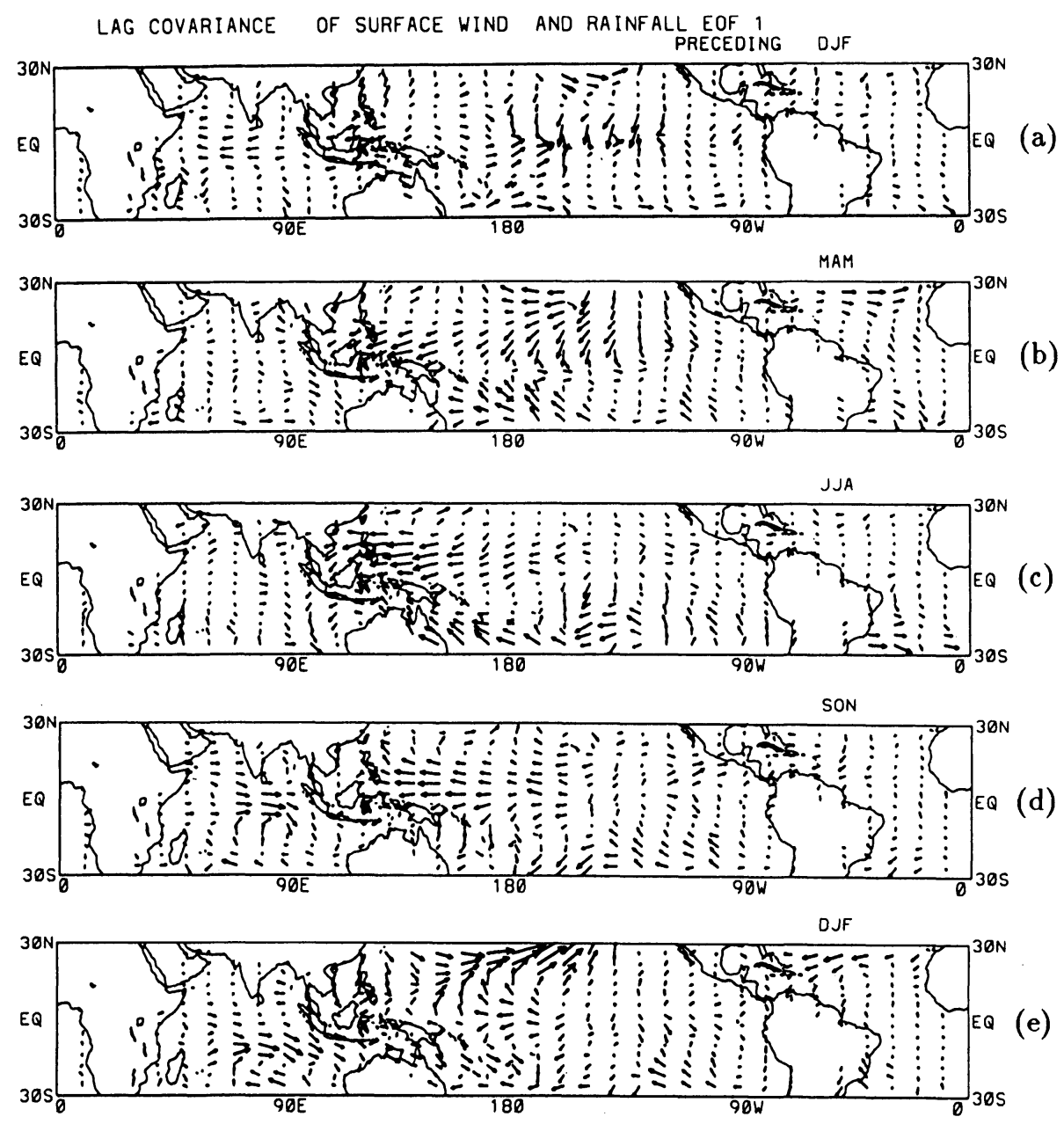

Fig. 13. Lag correlations vector field formed by the magnitude of the covariance between the zonal and the meridional surface wind components and the normalized first component of EAM rainfall. Pattern can be interpreted as the large scale pattern that projects onto the first principal component. Longest vectors correspond approximately of $1.5 \mathrm{~m} / \mathrm{s}$. 


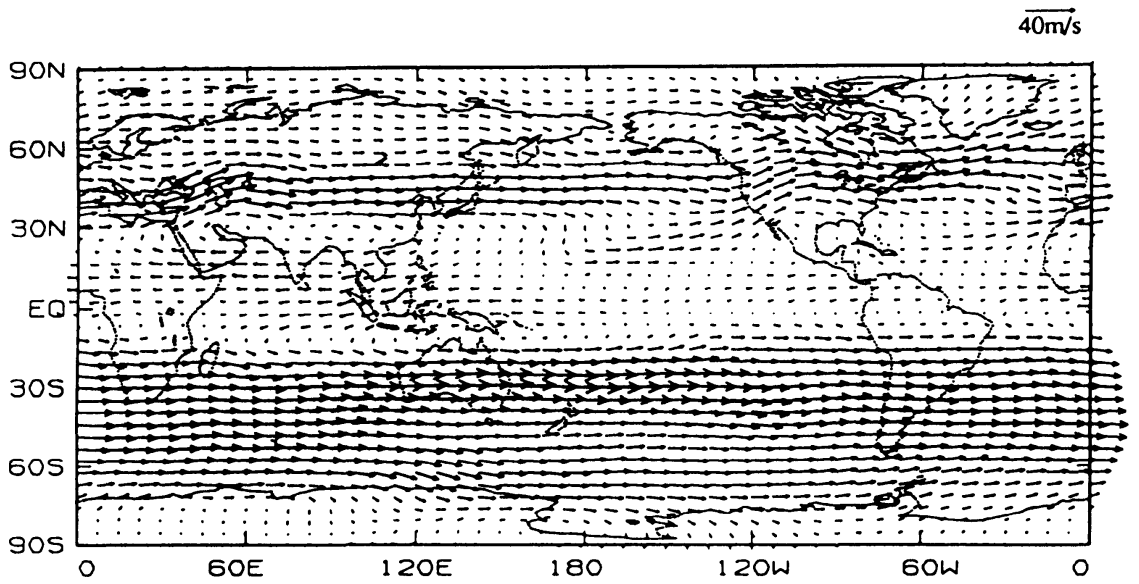

Fig. 14. Climatological JJA mean flow at $200 \mathrm{mb}$. Units in $\mathrm{m} / \mathrm{s}$.

the fall when the subtropical anticyclone moves eastward away from the coast region of East Asia. At this time surface westerlies begins to appear over the equatorial Indian Ocean. By DJF, the Indian Ocean westerlies become stronger and the center of the anticyclone is shifted to the central Pacific region. The South China Sea is now dominated by above-normal northerly flow indicating an enhanced winter monsoon (Lau et al., 1983). The large scale surface flow during SON and DJF is approximately a mirror image of that found during the preceding DJF in the equatorial region. This again implies a half-period of about 12 months, consistent with the presence of a biennial signal noted in the rainfall and the SST correlation.

\section{e. Atmospheric teleconnection}

The EAM has strong influence not only over the east Asian continent, but may have significant global influence through atmospheric teleconnection (Lau and $\mathrm{Li}, 1984$ ). Atmospheric teleconnection patterns are most easily seen in the upper troposphere, because it is farther removed from direct surface effects. Figure 14 shows the $200 \mathrm{mb}$ wind distribution for the northern summer (June-August). The EAM region is characterized by the anticyclonic flow around the Tibetan High centered around $30^{\circ} \mathrm{N}$, $100^{\circ} \mathrm{E}$, with zonal westerly flow around $45^{\circ} \mathrm{N}$ and easterly flow from the dateline across the Indian Ocean to Africa. Downstream of the East Asian jetstream is an upper level trough-ridge system over the eastern North Pacific and the US continent. A similar trough-ridge system is found upstream in the region of the Mediterranean Sea and the Caspian sea. The development of teleconnection patterns are strongly dependent on the dynamical properties such as refractive index, basic state vorticity advection associated with the above-mentioned features (Lau and Peng, 1991).

Figure 15 shows the first four principal atmospheric teleconnection patterns in the northern hemisphere based on rotated EOF analysis of 5-day mean $200 \mathrm{mb}$ streamfunction of ECMWF wind for June-August from 1980-1981. The EOF analysis is carried out with the seasonal cycle removed and only for the northern hemisphere to emphasize the teleconnection in the summer hemisphere. Because of the weaker potential vorticity gradient associated with the jetstream, the summertime teleconnection patterns are expected to be weaker than those of the winter hemisphere. A global analysis for the same period yields basically the same tropical modes as EOF1 but the extratropical modes are concentrated in the southern hemisphere. For the present, we focus on the northern hemisphere patterns only. The EOF 1 explains approximately $15 \%$ of the total variance. This mode features a wavenumber-one structure with centers over the subtropical western $\mathrm{Pa}$ cific and the Atlantic/North African region. The former is characterized by an east-west oriented feature over Indo-China and the subtropical western Pacific, near the western portion of the Tibetan High. To the north, there is an elongated band stretching from northeastern China to Japan coinciding with the Mei Yu/Baiu rainband during July to August. This pattern is related to the northsouth movement of the major monsoon convective zone associated with intraseasonal oscillations noted previously. A similar trough-ridge pattern is found over the Atlantic and eastern North America associated with the convection over mexico and the western Atlantic.

The second pattern (EOF2) explains $6.8 \%$ of the total variance. It consists of banded structures with large longitudinal but small meridional scale over the region of the climatological upper trough in the northeastern Pacific. Because the tropical convection is generally weak over this region and the largest amplitude is near $50^{\circ}-60^{\circ} \mathrm{N}$, this mode is likely to be an extratropical mode arising from downstream amplification of the East Asian jetstream. The third pattern (EOF3, 6.3\% variance) depicts a wave-like 

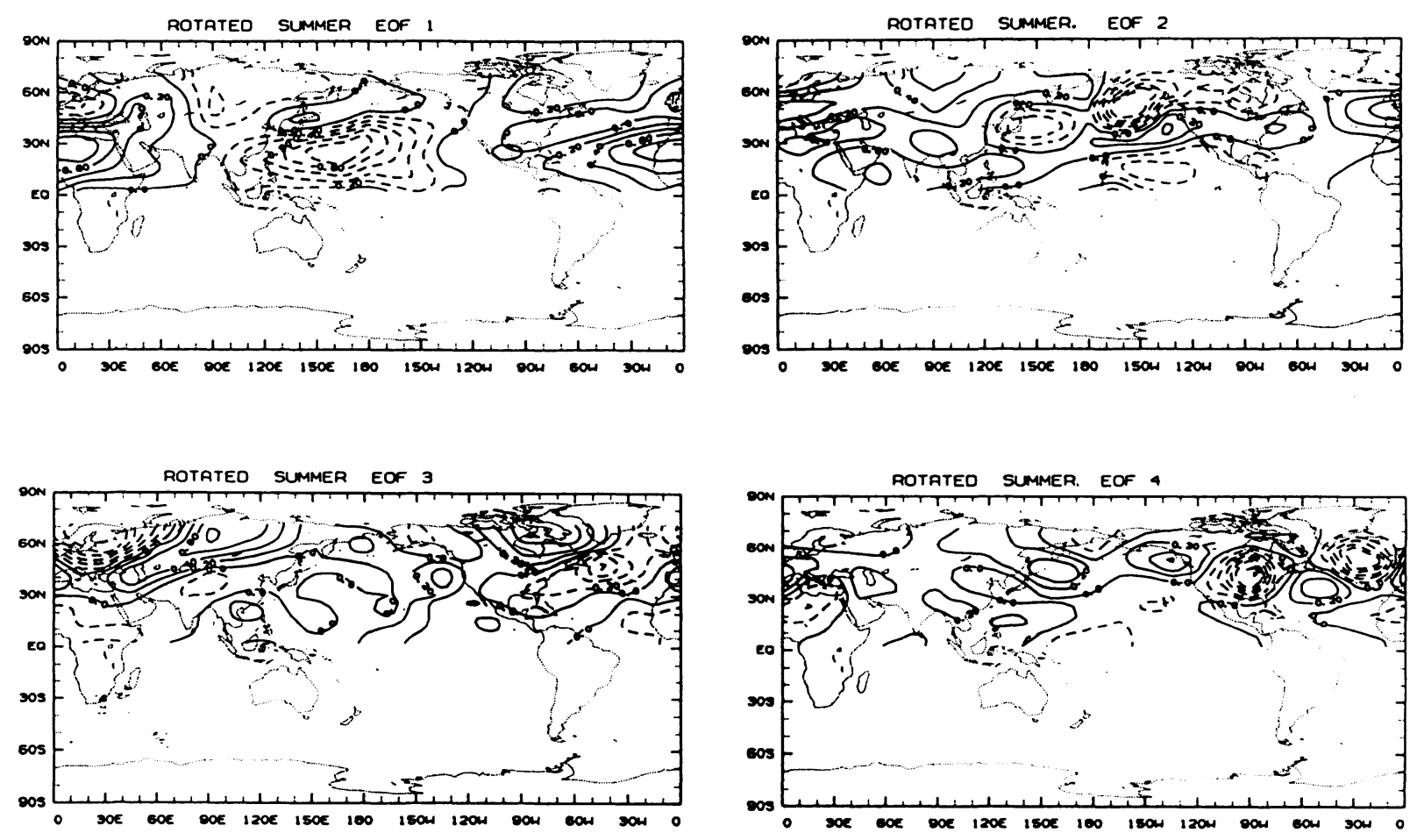

Fig. 15. Spatial patterns of first tour principal modes in $200 \mathrm{mb}$ streamfunction for the northern hemisphere based on 8 years of 5-day mean data for JJA. Units are arbitrary.

structure upstream of the monsoon trough region shown in EOF1. Here, the maximum amplitude is again in the extratropics near $60^{\circ} \mathrm{N}$ and the tilt of the structure suggests propagation of energy from midlatitudes to the tropics. This seems to be consistent with the observations that the $M e i-Y u$ or the Baiu front possesses extratropical characteristics in its northern section (Chen and Chang, 1980). The present results suggests that forcing in the extratropics can have an influence in the monsoon region in the low frequency time scale. A similar conclusion can be drawn for wave-like feature over the northeastern North America and the northwestern Atlantic.

The fourth pattern (EOF4) explains only about $4.5 \%$ of the total variance and is only marginally separated from the EOF noise spectrum. This mode is interesting, as it depicts a continuous wavetrain signal emanating form Indo-China along the coast of East Asian, via Japan and the Aleutians to North America. We shall refer to this as the ANA (AsiaNorth America) pattern. Although the variance explained by this mode is small, this mode appears to be stable with respect to different periods in the data and to the rotated EOF analysis. To examine the origin of this mode, we carry out a Singular Value Decomposition (SVD) analysis on the northern summer streamfunction with the OLR between $20^{\circ} \mathrm{S}$ to $20^{\circ} \mathrm{N}$ for the same period. The SVD seeks the dominant coupled patterns which maximize the covariance between two fields. A description of the method and results of some climate applications can be found in Bretherton et al. (1991) and Wallace et al. (1991). The detailed results of the summertime SVD analysis is out of the scope of this paper. Suffice it to say that the SVD analysis basically reproduces EOF1 shown in Fig. 15, coupled to a zonally oriented OLR anomaly that represents a north-south oscillation. The second and third SVD modes are associated with the east-west propagation of the intraseasonal oscillation. Of most interest in the context of atmospheric teleconnection is SVD-4 shown in Fig. 16. This mode explains $4.5 \%$ of the covariance between the streamfunction and OLR. Here, an extratropical wavetrain similar to the ANA pattern can be seen to be coupled to large anomalous heating over the Indian Ocean and western Pacific region. A wavetrain over Europe and the Middle East region, indicating equatorial propagation of energy is found upstream of the Indian ocean convection. The ANA pattern is similar to a wavetrain signal noted by Nitta $(1986,1987)$ and Kurihara and Tsuyuki (1987) during the opposite phase of ENSO. They attributed the development of the wavetrain to anomalous tropical heating over the Philippines. However, recent modeling experiments suggest that the ANA pattern is geographically fixed and may not be sensitive to the exact location of the heating provided they are in the tropical western Pacific. This fits the theoretical description of a marginally unstable mode of the summertime climatological flow. It should be noted that the normal 


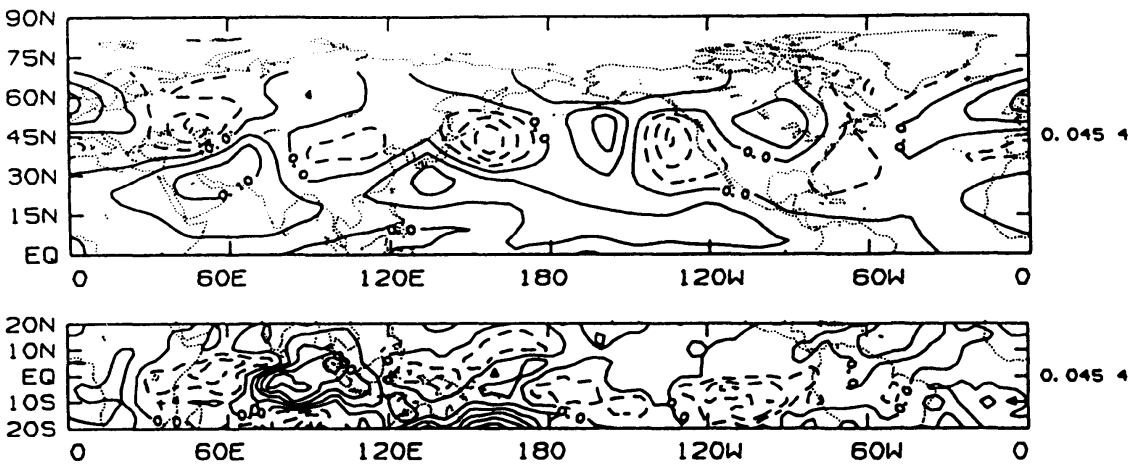

Fig. 16. Fourth principal mode of coupled OLR and streamfunction pattern based on Singular Value Decomposition showing the linkage of the Asian-North America pattern to heating in the monsoon region. Units are relative.

mode description is not in conflict with the tropical forcing description. More on the dynamics of teleconnection related to the ANA pattern will be discussed later.

\section{Modeling studies}

In the following, we present preliminary results of some recent theoretical and modeling studies with an aim to unravel the mechanisms of intraseasonal variation of the EAM, its influence by sea surface temperature anomalies and its role in the maintenance of atmospheric teleconnections.

\section{a. Simple modeling and theoretical studies}

The results presented in this section are based on experiments carried out using a 5-level dynamical model of the tropical atmosphere developed by Lau and Peng (1987). The basic model equations are linear except for the cumulus heating parameterization. A steady state monsoonal circulation is set up in the tropics by imposing a heat source at $22.5^{\circ} \mathrm{N}$ having a vertical heating profile with maximum heating around $500 \mathrm{mb}$. The $200 \mathrm{mb}$ steady state circulation resembles that shown Fig. 14 consisting of an upper level anticyclone and a mirrorimage cyclone in the lower troposphere. The three dimensional baroclinic circulation is held fixed and used as the basic flow for all anomaly experiments described in the following.

\section{(i) Time-longitude section}

With the mean flow and the monsoon heat source fixed, an equatorial 50-day disturbance is generated by introducing initially, a region of low level convergence over the equator upstream of the monsoon region at $0^{\circ}$ longitude. As a result of the mobile wave-CISK mechanism, a "supercluster" which has an eastward propagating speed of about $10 \mathrm{~m} / \mathrm{s}$ is generated (Hayashi and Sumi, 1986 and Lau and Peng, 1987). Figures $17 \mathrm{a}$ and $17 \mathrm{~b}$ show the timelongitude section of the precipitation pattern at the equator and at $16^{\circ} \mathrm{N}$ respectively, where Day 0 cor-
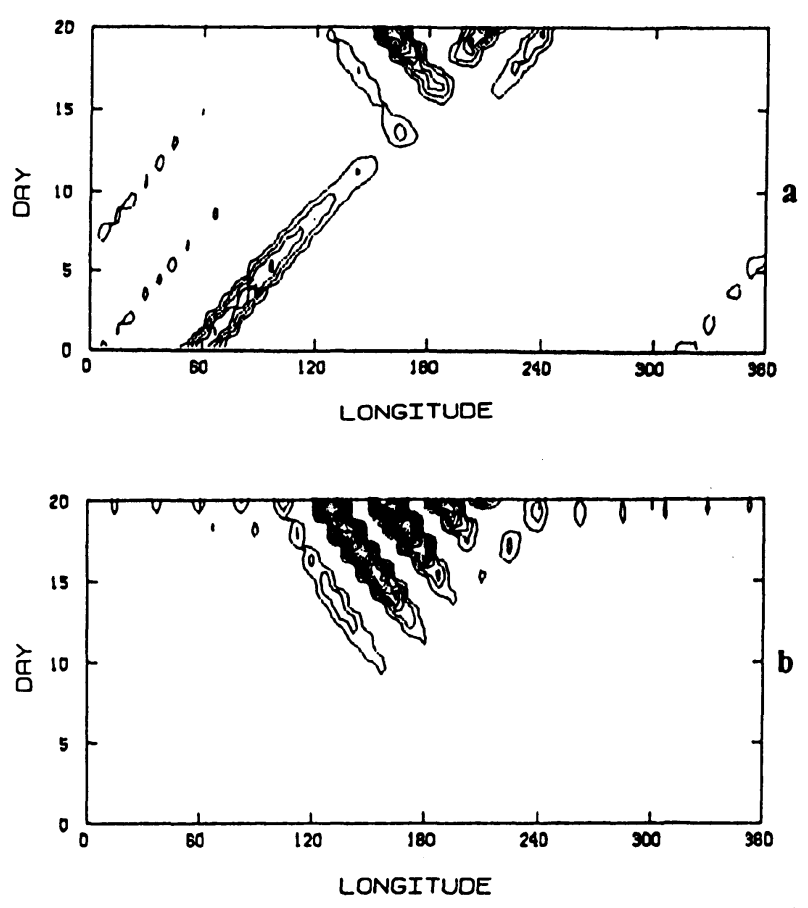

Fig. 17. Time-longitude section of model precipitation (a) along the equator and (b) at $16^{\circ} \mathrm{N}$. Contour interval is in $5 \mathrm{~mm} /$ day.

responds to the time when the supercluster is located at $60^{\circ}$ longitude. At the equator (Fig. 17a), the precipitation is dominated by that associated with the propagating supercluster. There are secondary but much weaker precipitation bands trailing behind the supercluster. These secondary precipitation patterns are associated with transient circulation features generated away from the supercluster. As the supercluster approaches the monsoon region, it is seen to weaken considerably and new westward propagating precipitation patterns appear over the monsoon region. At Day 20, a new eastward propagating but weaker precipitation pattern appears to 
re-emerge from the monsoon region. There is a dramatic development over the monsoon region, as a result of the approach of the equatorial disturbance (Fig. 17b). At $16^{\circ} \mathrm{N}$, successive precipitation centers are generated over the monsoon region ahead of the approaching equatorial disturbance. Each of the precipitation centers intensifies and migrates westward with a speed approximately the same as the equatorial eastward disturbance. The amplification suggests a growth rate with e-folding time of a few days. By Day 20, the maximum rainfall has reached a peak value of over $50 \mathrm{~mm} /$ day. Because of the linear nature of the solution, the amplitude of the disturbance near the end of the integration is too large and should not be taken too seriously. Only the phase should be emphasized.

\section{(ii) Horizontal and vertical structures}

Figure 18 shows the sequence of rainfall maps every two days apart, starting from Day 8 when the equatorial disturbance enters the monsoon region. From Day 10, precipitation centers begin to emerge at about $20^{\circ} \mathrm{N}$ in the monsoon region upstream of the equatorial center which begins to weaken. At around Day 16, the center of action has abruptly shifted to the region of the monsoon heat source where two rainfall centers are observed. It appears that these centers are formed upstream near the ascending leg of the mean Hadley circulation (near $180^{\circ}$ ) and then migrate westward and dissipate as they move out of the monsoon region. By Day 18, rainfall over the monsoon heat source region is excessive. Similar maps for the horizontal wind field at $700 \mathrm{mb}$ (Fig. 19) show that the initial disturbance is maintained by strong zonal wind convergence near the equator in Day 8-10. As the equatorial disturbance weakens, westward propagating cyclonic circulations are generated over the monsoon region. Strong low level southwesterly flow are found on the equatorward side of the leading (westernmost) disturbance. By Day 18, three distinct cyclones are formed over the monsoon region. Each of the cyclonic center is accompanied by a rainfall center slightly to its east (see also Figs. 17 and 18).

The changes in the local Hadley circulation at $180^{\circ}$ as a result of the interaction of the $30-60$ day supercluster and the monsoon circulation are depicted in Fig. 20. The vertical circulation for Day 6 indicates sinking motion at the equator and all other latitudes. This corresponds to the descending branch of the equatorial Walker-type circulation associated with the initial 30-60 day disturbance when its center is far upstream of the monsoon region. At Day 12, when the equatorial disturbance enters the monsoon region, a Hadley type circulation is generated, with two ascending legs, over $5^{\circ} \mathrm{S}$ and $15^{\circ} \mathrm{N}$ respectively. The northward shift of the heating center is very abrupt and occurs around Day 18-24,
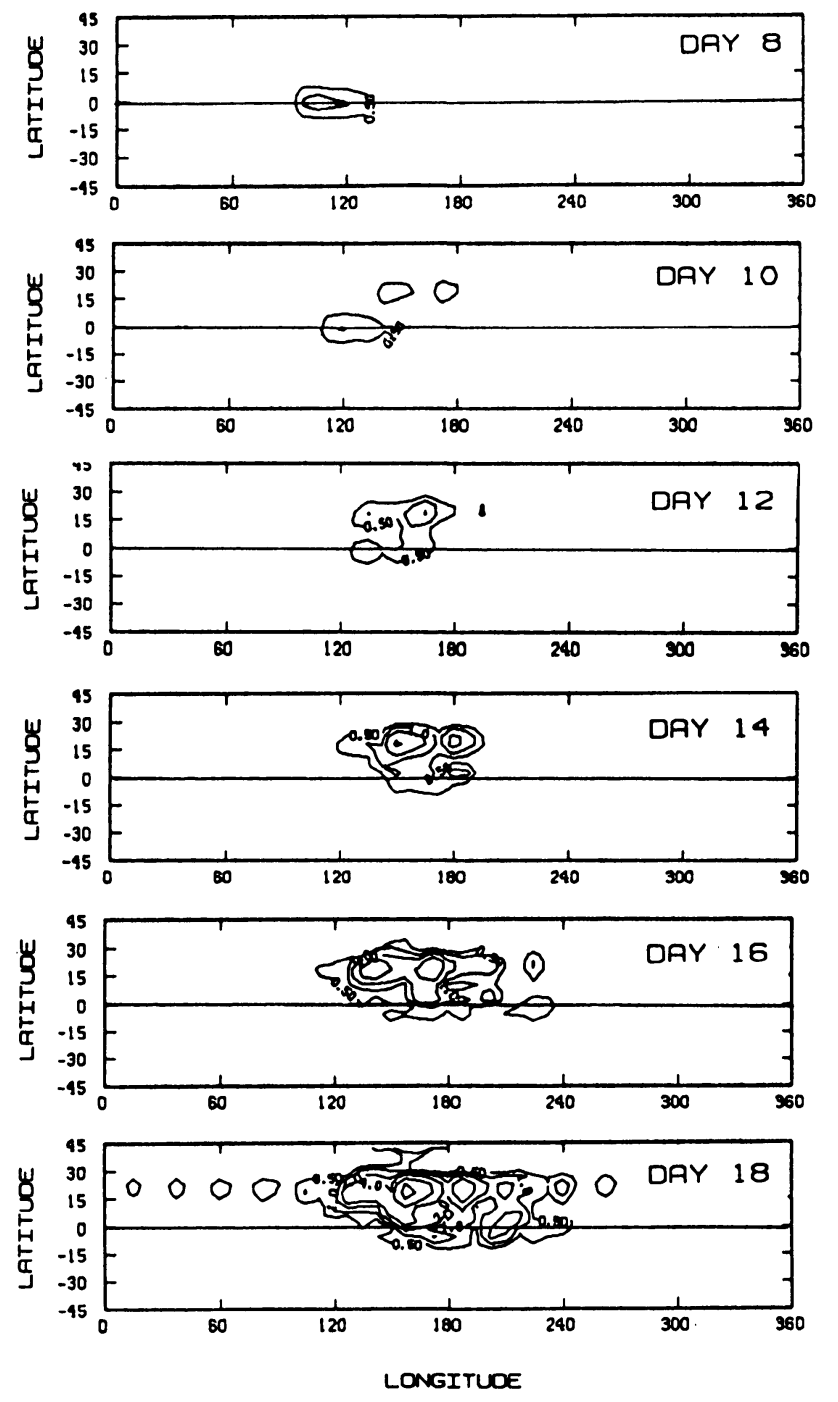

Fig. 18. Sequence showing changes in precipitation pattern at 2-day interval as the 30 60 day disturbance approaches the monsoon region (120-180 longitude) along the equator. Contour interval is variable.

when a single Hadley-type circulation is developed with a center at $20-30^{\circ} \mathrm{N}$. The northward shift of the anomalous circulation center is somewhat similar to the sequence of northward propagation of the monsoon rainband over East Asia discussed in the previous sections.

\section{(iii) Linkage to western Pacific superclusters}

In a separate study, Nakazawa (1988) and Lau et al. $(1989,1991)$ have shown that supercluster organization over the equatorial western Pacific involves eastward propagating moist Kelvin waves and the formation of westward propagating synoptic scale Rossby wave-like motions with $2-3$ days periods. Based on GMS observations and the above theoretical results, Lau (1990) has proposed a mechanism for multi-scale interactions linking the superclus- 

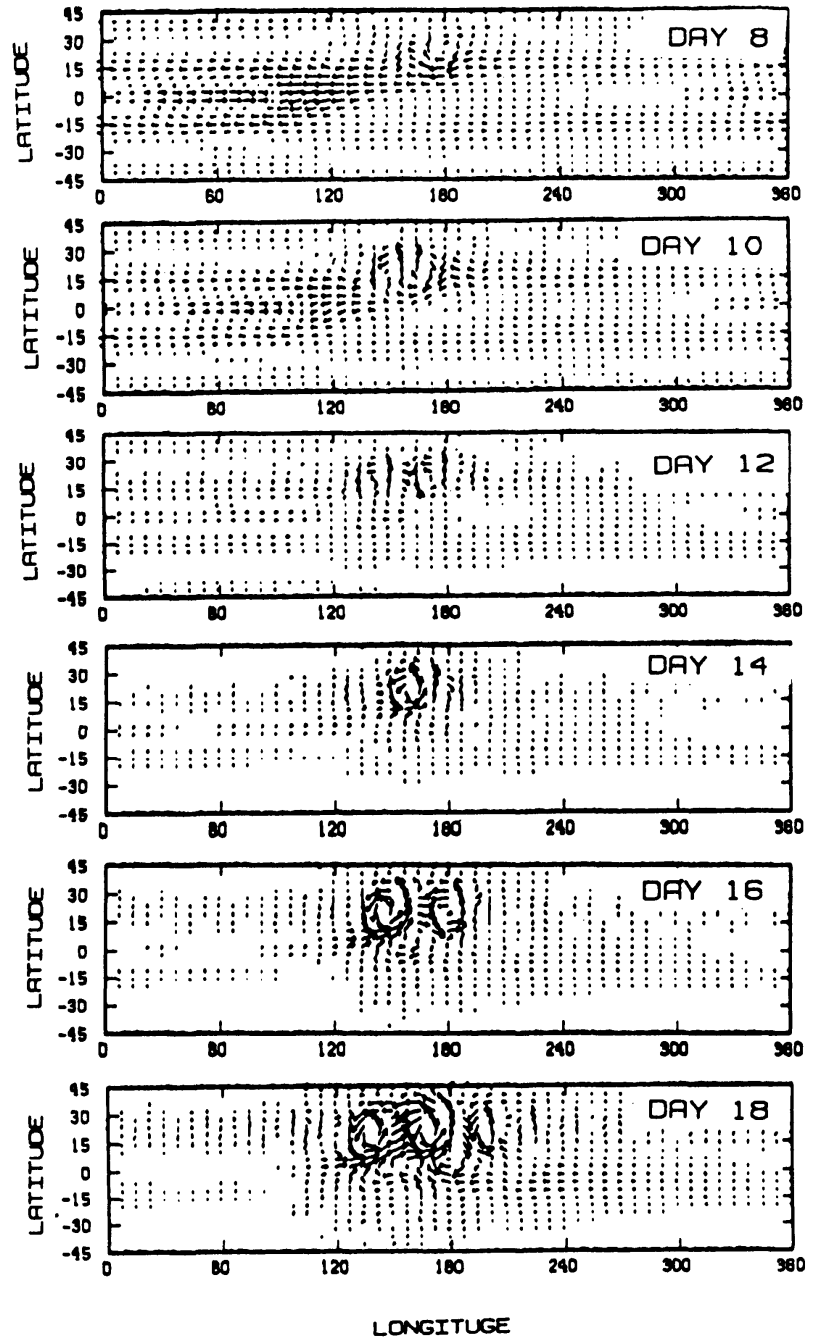

Fig. 19. Same as in Fig. 18, except for $700 \mathrm{mb}$ wind. The magnitude of the wind vector has been scaled with the maximum wind at the corresponding day.

ters in the western Pacific to the variability in the EAM. This is shown schematically in Fig. 21. During JJA, deep convection associated with eastward propagating ISOs in the equatorial region, shifts rapidly northward as the ISO propagates into the EAM region from the Indian Ocean. Concurrently the amplitude of the intraseasonal oscillation is diminished at the equator near the longitude of the EAM. Convection associated with the ISO undergoes a major reduction over the maritime continent before it becomes enhanced over the western Pacific warn pool. This re-enhancement is accompanied by the formation of superclusters and westward propagating waves. It is hypothesized that the westward propagating disturbances are gravest Rossby waves excited in the dynamical adjustment processes between latent heating and the circulation field. As a result of the steering mean easterlies in the southern flank of the West Pacific Subtropical High, some
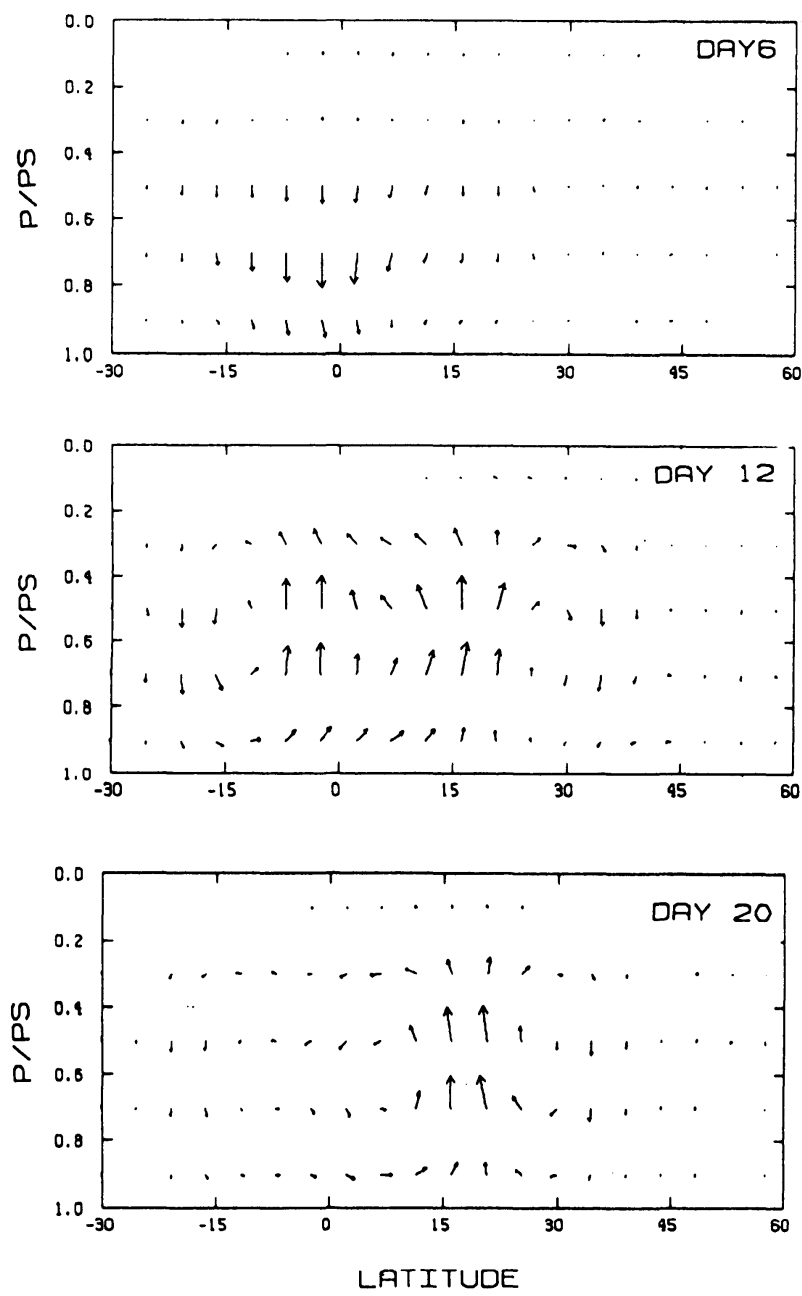

Fig. 20. Latitude-height cross-section showing the changes in the meridional circulation at 180 longitude as the equatorial disturbance approaches the monsoon region from the west.

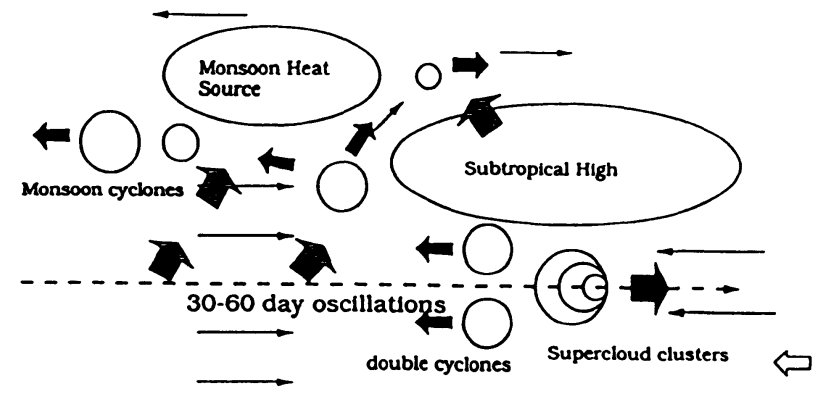

Fig. 21. Schematic showing the relative motion of EAM disturbances, ISO and western Pacific equatorial superclusters with respect to the monsoon heat source and the Subtropical High. The direction of motion of synoptic scale disturbances, the ISO are indicated by dark and shaded arrows respectively. Thin arrows indicate the direction of the mean flow. 
of the equatorial westward propagating disturbances are steered by the low level easterlies into the EAM region and then around the Subtropical High into the northwestern Pacific (Lau and Lau, 1990). Others are advected into the EAM region where the mean vertical shear is large. The large vertical shear may be the source of dynamical instability induced by the abundant moisture and heat in the subtropical western Pacific upsteam of the EAM region leading to easterly waves or monsoon cyclone genesis upstream and in the EAM region (Lau and Peng, 1990). The above picture emphasizes the equatorial western Pacific warm pool as a region for genesis of multi-scale disturbances including tropical cyclones and precursors of monsoon disturbances.

\section{b. GCM studies}

In the 1980's a large number of general circulation model (GCM) studies of atmospheric response to SST have been carried out. Because the strongest teleconnection patterns that have been related to tropical SST are found in the winter hemisphere, most of the GCM studies have been conducted only for the northern winter. By comparison, GCM studies of SST forcing during the northern summer are relatively few. Keshvarmurty (1982) studied the atmospheric response to idealized' SST anomalies during northern summer. Tokioka et al. (1985) investigated the atmospheric response to realistic SSt forcing during the summer of 1983. Recently, there are renewed interests in the study of monsoon climate by the World Climate Research Program (WCRP). Under the tropical Ocean Global Atmosphere (TOGA), Monsoon Numerical Experimentation Group (MONEG), dedicated efforts to study the seasonal predictability of monsoon rain and circulation using GCMs are being carried out (Palmer et al., 1990). In the following, we present a brief review, based on recent GCM studies of the seasonal and interannual variation of the EAM.

\section{(i) Seasonal and intraseasonal variations}

This section describes some preliminary results based on the US-PRC Joint Monsoon Research Project to study the impact of large scale SST anomaly such as El Nino on the EAM using a general circulation model developed at the Institute of Atmospheric Physics (IAP), Academia Sinica. Only the results of the seasonal variation will be discussed here. These results are based on an eight-year integration with climatological SST, performed using a two-level version of the IAP GCM having a $4^{\circ} \times 5^{\circ}$ latitude-longitude horizontal resolution. The model has full physics including interactive clouds. Details of the model physics and numerics are described in Zeng et al. (1990). The results are typical of the capability of state-of-the-art GCMs to simulate the seasonal variation of the East Asian monsoon.

Figure 22a and 22b show the observed and sim- ulated surface global pressure field for the month of July. The simulated pressure field was based on the mean July condition of the last year of a 8-year model integration. It can be seen that the model produces quite realistically the subtropical high pressure centers over the Pacific and the Atlantic respectively. In particular, the Pacific subtropical high which has a strong control over the monsoon rainfall of East Asia is well simulated. The model produces spurious low pressure centers over the Tibetan Plateau and the southwestern US continent. This may arise as a result of the poor treatment of topography due to the low vertical resolution of the model. Figure 23a and 23b show the "observed" and simulated July precipitation pattern. The model and observed rainfall show fairly good agreement. Over East Asia, the main feature includes a strong monsoon precipitation zone over the western Pacific and the Indian Ocean featuring a distinct rainband that stretches from southern China to Japan. This rainfall band may be identified with the $M e i-Y u$. However, this band is shifted much farther northward than observed. Moreover, the model $M e i-Y u$ band completely misses Japan. Other unrealistic features include spurious rainfall over the equatorial central Pacific, the southeastern coast of North America and the southern tip of Africa, as well as the lack of rainfall over Central America. Undesirable regional features such as the above are not uncommon in state-of-the-art low-resolution climate models. Some of them may be alleviated by better representation of the topograph by going to higher resolution. However, the real remedy lies in better representation of the physics in the cumulus parameterization used in GCM.

Figure 24 shows the time-latitude section of the 5-day mean $400 \mathrm{mb}$ zonal wind for a typical model year. During most part of the year except JJA, the zonal flow is quite steady with the center of the westerly jet at $30^{\circ} \mathrm{N}$. During June to August, the westerly jet is substantially weakened and the jet axis is re-established near $40^{\circ} \mathrm{N}$. This is accompanied by a corresponding increase in the upper level easterly in the vicinity of the equator and $10^{\circ} \mathrm{S}$. This period corresponds to the northward penetration of the EAM rainband into the extratropics. Figure $25 \mathrm{a}$ and $25 \mathrm{~b}$ show the time-latitude cross-section of 5 day mean precipitation averaged over the East Asian region $\left(110-125^{\circ} \mathrm{E}\right)$ for two independent years. Although there are substantial amount of interannual variability between the two years, the evolution of the overall pattern is quite similar. From January to March, the major precipitation is confined to the equatorial region. The abruptness of the onset of the monsoon rain over East Asian is clearly seen as the rainband jumps from the equatorial region to $10^{\circ}-20^{\circ} \mathrm{N}$ between April to early May and then from $10^{\circ} \mathrm{N}$ to $15^{\circ}-20^{\circ} \mathrm{N}$ between May to June. In the be- 

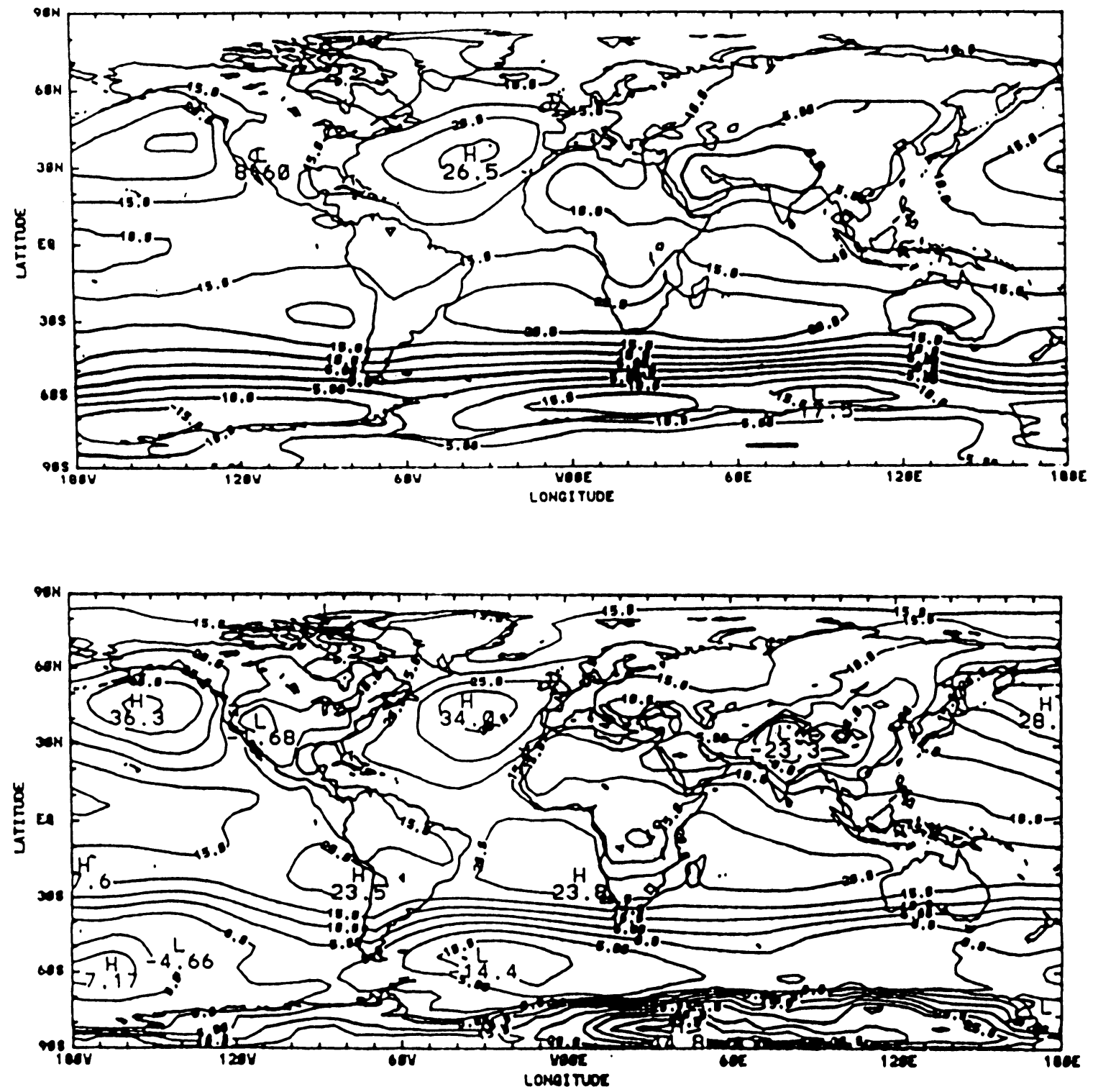

Fig. 22. (a) Observed sea level pressure pattern for July. Labels show units in mb with $1000 \mathrm{mb}$ subtracted. (b) Same as in Fig. 22a except for sea level pressure in the IAP GCM.

ginning to middle July, the rainband penetrates further northward to $40^{\circ} \mathrm{N}$, leaving the central region near $20-30^{\circ} \mathrm{N}$ relatively dry. The monsoon rain in central East Asia returns in August and September. All through the rainy period lasts from April to September, there are obvious intraseasonal oscillations with periods of about 20-30 days following the onset. This entire sequence remarkably resembles that shown in Fig. 3a.

Figure $26 \mathrm{a}$ and $26 \mathrm{~b}$ show the variation of 10-day mean $850 \mathrm{mb}$ wind and the sea level pressure averaged at $150^{\circ} \mathrm{E}$ as a function the march of the season for two independent years. In both cases, the characteristic southwesterly monsoon flow starts from early May and progresses northward until late July or August. This.is followed by a break in the monsoon, whereby the low latitude flow changes briefly into easterlies and the subtropical high (marked by the dashed line) reaches its northern extreme latitude near $40^{\circ} \mathrm{N}$. The equatorial low pressure trough (marked by thick solid line) or ITCZ also shows a gradually northward migration from June to $\mathrm{Au}$ gust in concert with the northward movement of the subtropical high. In the midlatitudes, the pressure field exhibits a significant intraseasonal oscillation with approximately 30-day periods. Comparing the two cross-sections, in one year, the subtropical high reaches its maximum northerly position in early $\mathrm{Au}$ gust and in late August in another year. This indicates the onset of monsoon rain in northern China can occur within 3-4 weeks due to year-to-year internal variability of the system even in the absence of SST anomalies forcing. 

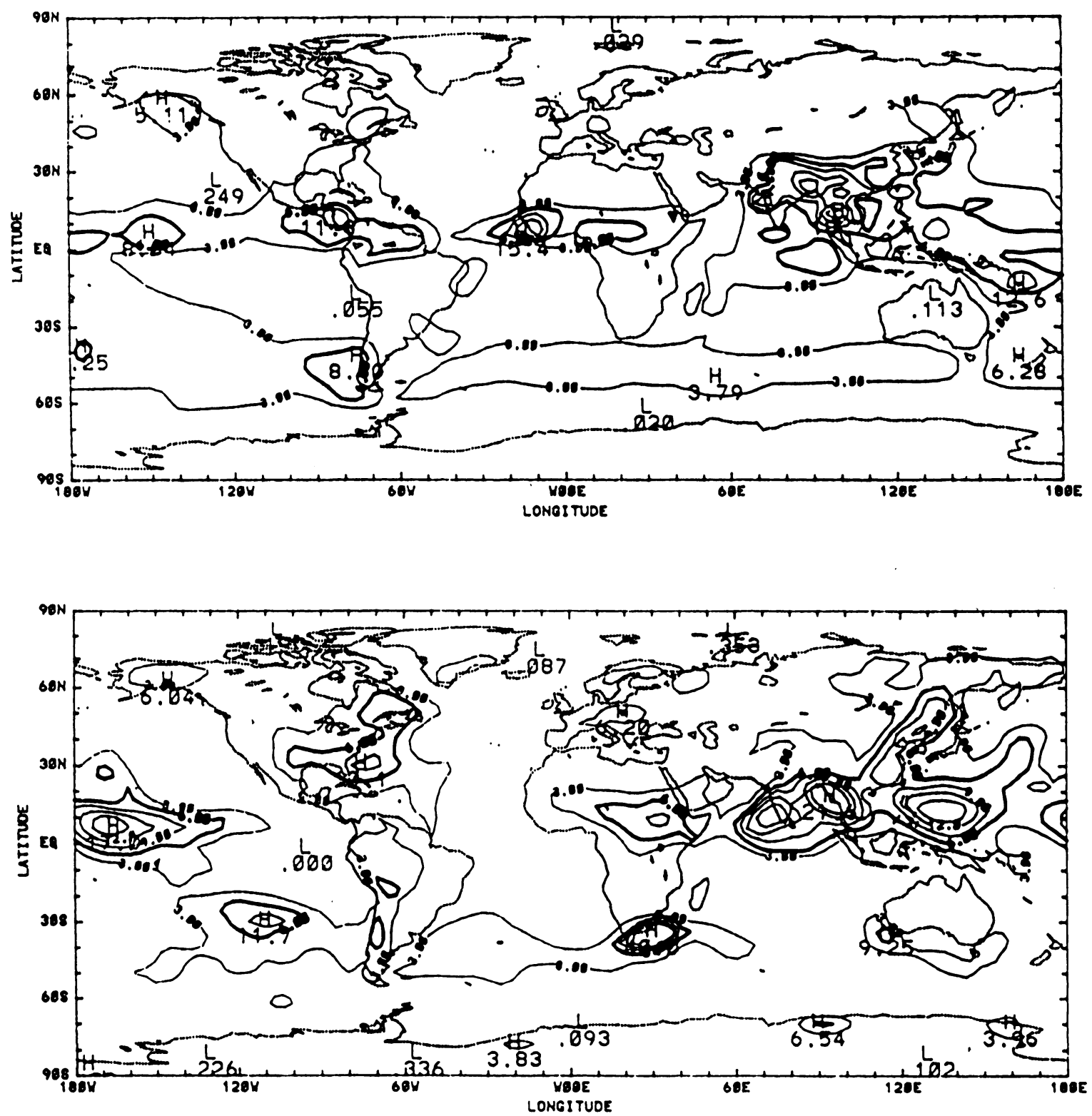

Fig. 23. (a) Observed climatological July global rainfall distribution based of Jaeger (1976). Units in $\mathrm{mm} /$ day. (b) Global rainfall distribution in the IAP GCM. Units in $\mathrm{mm} /$ day.

\section{(ii) SST influences}

As noted in the previous sections, interannual variability of the EAM is closely related to the changes in precipitation and SST in the equatorial regions from the Indian Ocean to the eastern $\mathrm{Pa}$ cific. Up to now, GCMs have reproduced rather realistic planetary scale tropical circulation changes associated with the EAM, arising from large scale basin-wide SST anomalies. However, the simulation of the regional features associated with the EAM has not been quite successful. We shall illustrate the changes in the planetary scale circulation due to large scale SST anomalies by using results from the MRI model (Tokioka et al., 1985). Typically, for a east-west SST anomaly such as that occurs during an ENSO, the rising branch of the equatorial
Walker circulation is shifted from its climatological position eastward to the central Pacific. During extreme events such as the 1983 ENSO, the equatorial Walker circulation may even be reversed. Figure 27 shows the anomalous east-west circulation along the equator produced by the MRI GCM during the June 1983. This period represents the mature stage of the 1982-83 ENSO, when the SST anomaly over the eastern Pacific is about $2^{\circ} \mathrm{C}$ above normal. The most conspicuous feature is the large anomalous rising motion over the warm water of the eastern Pacific. The subsidence motion of the Walker cell is widespread over the Indian Ocean, the central and western Pacific. The descending branches are found between $30^{\circ}-90^{\circ} \mathrm{E}$ and $180^{\circ}-150^{\circ} \mathrm{W}$. However, not all the subsiding air over the Indian Ocean and west- 


\section{U AT 400MB (M/S) BY IAPGCM 5-DAYS AVERAGED $110 \mathrm{E}$ - 130E MEAN}

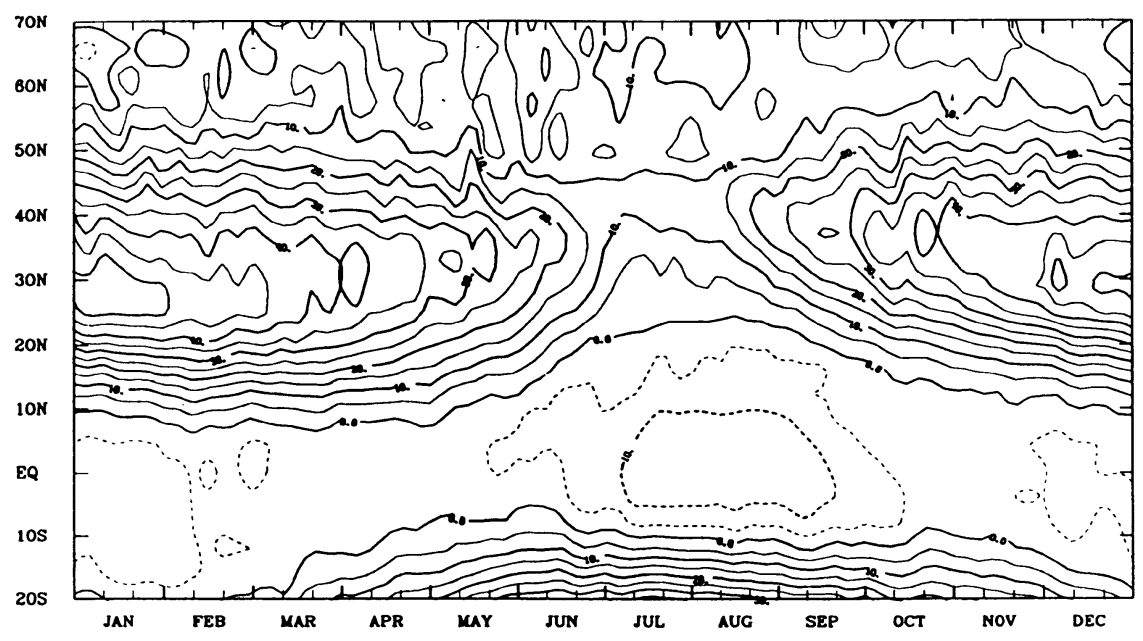

Fig. 24. Seasonal variation of zonal wind at $400 \mathrm{mb}$ in the IAP GCM. Units in $\mathrm{m} / \mathrm{s}$.

ern Pacific come from the eastern Pacific but some may arise from local meridional circulation over the Indian and EAM region. Figure 28 shows that local Hadley circulation over the Indian Ocean $\left(30^{\circ} \mathrm{E}-\right.$ $\left.120^{\circ} \mathrm{E}\right)$ and the western Pacific $\left(120^{\circ} \mathrm{E}-160^{\circ} \mathrm{E}\right)$ respectively. In both regions, strong ascending motion is found at $30^{\circ} \mathrm{N}$. Coupled with the sinking motion at the equator, they constitute an enhanced local Hadley circulation indicating increased monsoon activities over the Indian monsoon and EAM region.

Figure $29 \mathrm{a}$ and $29 \mathrm{~b}$ shows respectively the 800 $\mathrm{mb}$ and the $200 \mathrm{mb}$ wind response during June 1983 . The $800 \mathrm{mb}$ flow indicates there are anomalous easterlies over the eastern Pacific and westerlies in the western Indian Ocean (Fig. 29a). The zonal wind distribution is consistent with widespread sinking motion over the Indian Ocean and the western Pacific. Off the coast of East Asian region, the wind anomaly is southwesterly but rather weak. However, it is in the same direction as the climatological surface monsoon flow and therefore suggests an enhancement of the EAM. This is in agreement with the observations that a warm eastern Pacific generally precedes above normal EAM rainfall (see discussion in Section 2). The $200 \mathrm{mb}$ flow is easterlies in the equatorial eastern Pacific indicating a baroclinic structure extending throughout the troposphere. There are two anticyclonic circulation cells flanking the equatorial easterlies on opposite sides of the equator characteristic of the wind response to tropical heating (Lau and Lim, 1982). In contrast, the anomaly over the equatorial western Indian ocean is confined near the lower troposphere as indicated by the absence of a strong signal at 200 $\mathrm{mb}$ in that region.

In the extratropics, there are noticeable circulation features induced either directly or indirectly by the anomalous SST forcing. As expected, the largest response is in the southern (winter) hemisphere where there is a strong wintertime westerly jetstream to facilitate energy transport from tropics to extratropics. A distinct wavetrain is seen emanating from the SPCZ to the southern tip of South America and the southern Atlantic Ocean. Comparison between the $200 \mathrm{mb}$ and $800 \mathrm{mb}$ flow confirms that the wavetrain is barotropic in nature. In the northern (summer) hemisphere, there is a strong circulation pair in the lower troposphere in the vicinity of the Aleutian Islands and Kamchaka Peninsular. The former has a barotropic structure with a pronounced signal in the upper troposphere while the latter is more confined to the lower troposphere. At $200 \mathrm{mb}$, the Aleutian cyclonic circulation appears to be part of a wavetrain signal extending from Eurasia to North America. This however does not resemble the ANA signal noted in previous sections.

\section{c. Dynamics of the Asia-North America (ANA) teleconnection}

There is now a growing body of evidence suggesting the existence of atmospheric teleconnection pattern similar to the ANA, linking EAM heating to far field influence on North America via the Aleutians (Nitta, 1986, 1987, Kurihara, 1989). Results from linear barotropic model suggest that the ANA pattern is the result of Rossby wave dispersion due to anomalous heating over the Philippines (Nitta, 1987, Huang, 1990). Recently, Lau and Peng (1991, hereafter referred to as LP) carried out a series of experiments using a low resolution (R15) nonlinear barotropic model to study the dynamics of atmospheric teleconnection during the northern summer. They concluded that an atmospheric teleconnection pattern similar to the ANA may be due to the pres- 

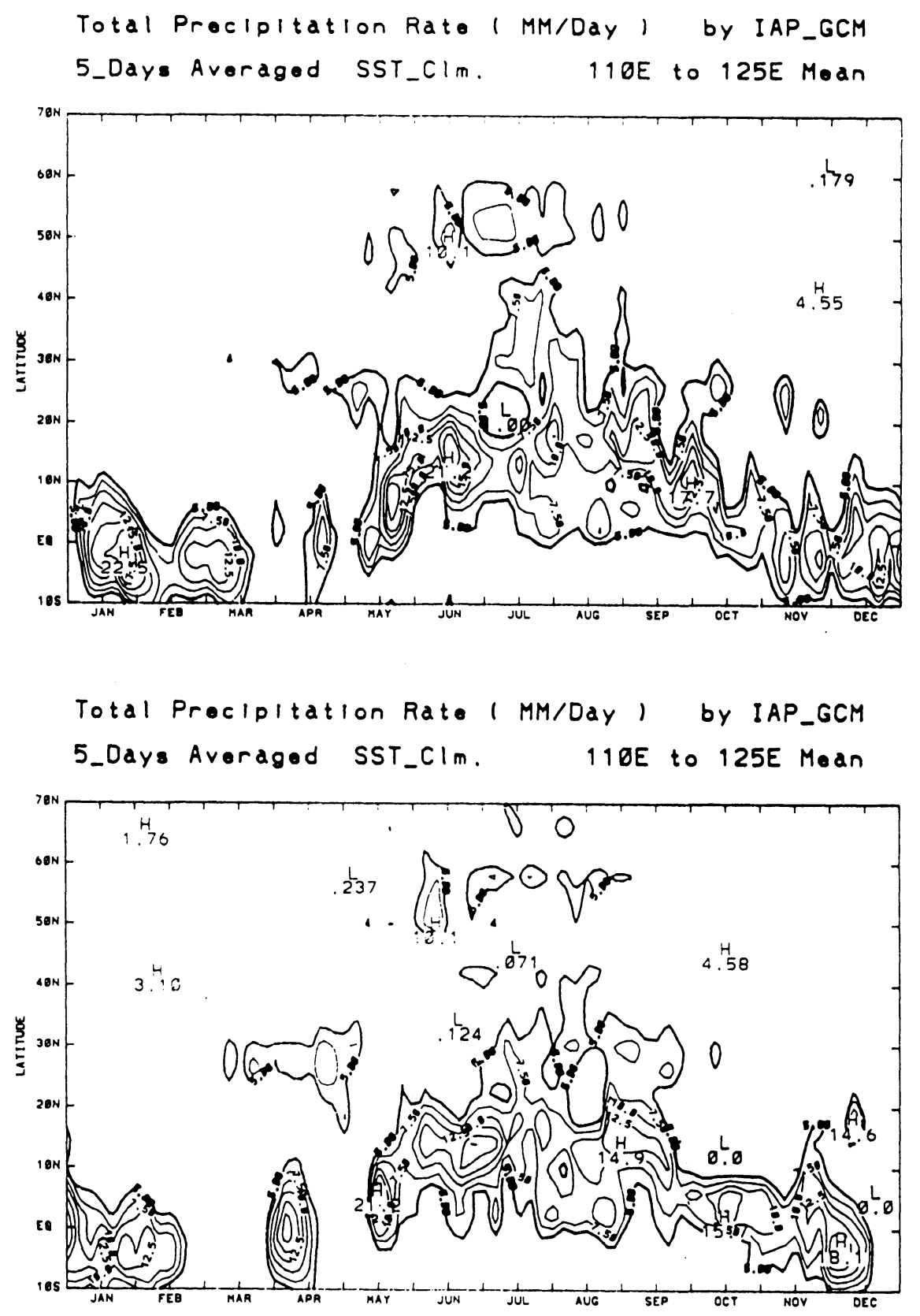

Fig. 25. Time latitude sections of EAM 10-day mean rainfall averaged between $110^{\circ} \mathrm{E}-125^{\circ} \mathrm{E}$ showing seasonal variation of EAM rainfall for (a) year-3 and (b) year-4 in the 8-year control integration of the IAP GCM using climatological SST.

ence of a marginally unstable normal mode in the northern summer climatological mean flow. The following is a discussion of the dynamics of the summertime teleconnection in support of the normal mode description. The model used is a barotropic nonlinear model similar to that used in LP, except with a higher (R30) resolution. The model uses as the basic flow, the climatological June mean circulation including the divergent wind. The mean zonal flow is fixed throughout the integration, but the basic flow is kept approximately invariant by an "eddy" forcing term which restores the mean flow to its climatological values. While LP used idealized heating the present model uses "realistic" heating based on observed OLR of May and June 1988 (Fig. $30 \mathrm{a}$ and $30 \mathrm{~b})$. These particular months correspond to the cold event or La Nina of 1988, when SST is abnormally cold in the equatorial eastern Pacific and abnormally warm in the western Pacific. Extreme drought and flood conditions were experienced from East Asia to North America. During these two months, the anomalous heating pattern in the tropics is quite different. In May, enhanced convection denoted by negative values of OLR can be found in 
the LATITUDE - TIME SECTION OF SLP AND W_850 10_DAY MEAN. MAY - SEP.. HT 150 E. FQR C

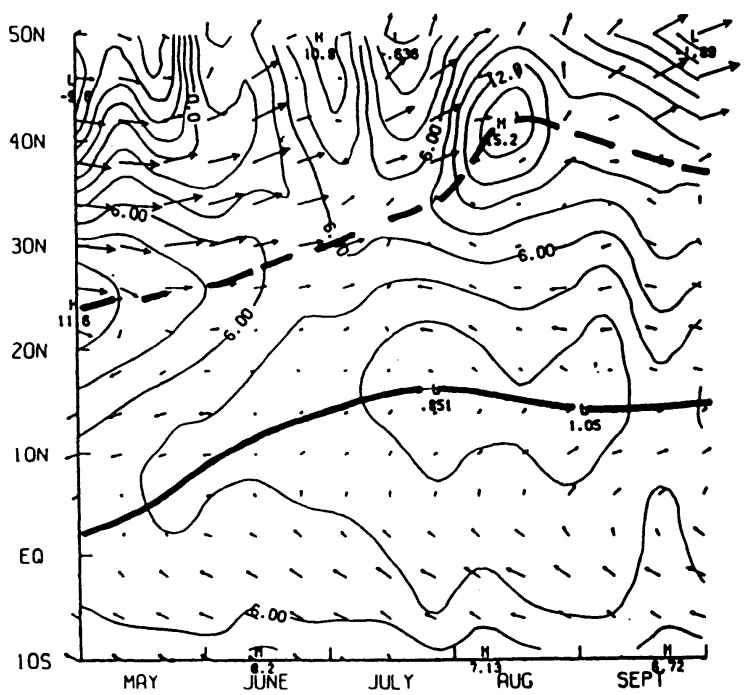

THE LATITUDE - TIME SECTION OF SLP AND W_850 10.DAY MEA:1. MY - SEP., AT 150 E. FOR S

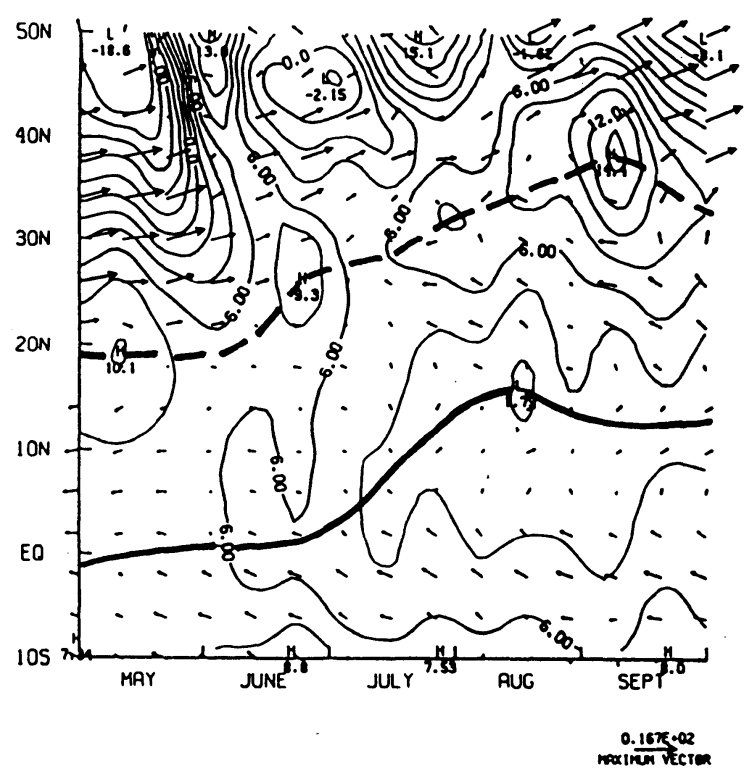

Fig. 26. Time-latitude cross-section of 10-day mean surface pressure and $850 \mathrm{mb}$ showing seasonal and intraseasonal variations during (a) year-3 and (b) year- 4 of the IAP GCM control run. Trough and ridge axes are marked by heavy dotted lines.

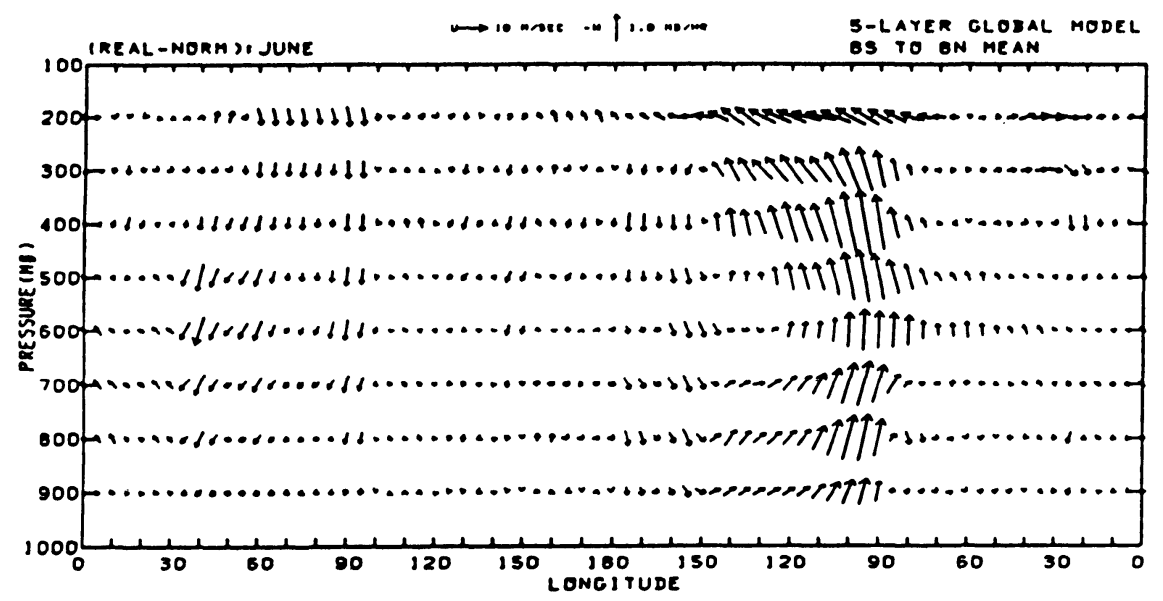

Fig. 27. Monthly mean anomalous circulation during June 1983 in the equatorial plan $\left(8^{\circ} \mathrm{N}-8^{\circ} \mathrm{S}\right)$ due to influence of the above-normal SST in the equatorial eastern Pacific in the MRI GCM. Results are adopted from Tokioka et al. (1985).

the monsoon region of Western Pacific and the Indian Ocean. In contrast, the June anomaly depicts an elongated north-south OLR anomaly in the equatorial central and eastern Pacific. The anomaly in the eastern Pacific has been suggested as a possible cause of the 1988 drought over North america (Trenberth et al., 1988). To translate the OLR to heating pattern, we used the following empirical formula to scale the OLR pattern to the upper level divergence,

$$
D=\left(-.05 \times 10^{-6}\right) \times \cos ^{4} \phi \times \text { OLR }
$$

As a result of the $\cos ^{4} \phi$ factor, only anomalies within 20 degree of the equator contribute significantly to the heating. It should be emphasized that the purpose of the following discussion is not aimed at a simulation of the actual 1988 anomalous circulation, but rather as a test of the sensitivity of the model response to different heating distribution in the tropics. Figure 31 shows forcing the response 

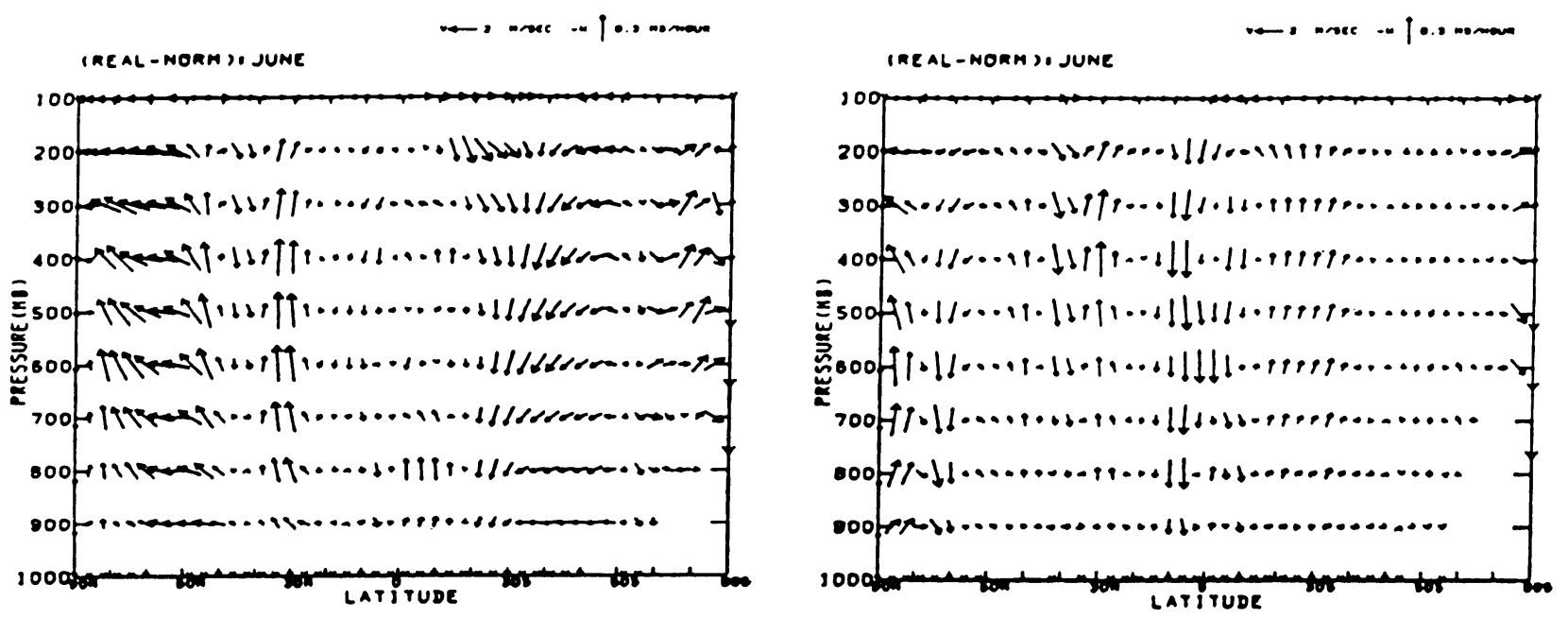

Fig. 28. Same as in Fig. 27, except for the local meridional circulation in (a) the western Pacific $\left(120^{\circ} \mathrm{E}-\right.$ $\left.160^{\circ} \mathrm{E}\right)$ and $(\mathrm{b})$ the Indian Ocean $\left(30^{\circ} \mathrm{E}-120^{\circ} \mathrm{E}\right)$. Adopted from Tokioka et al. (1985).
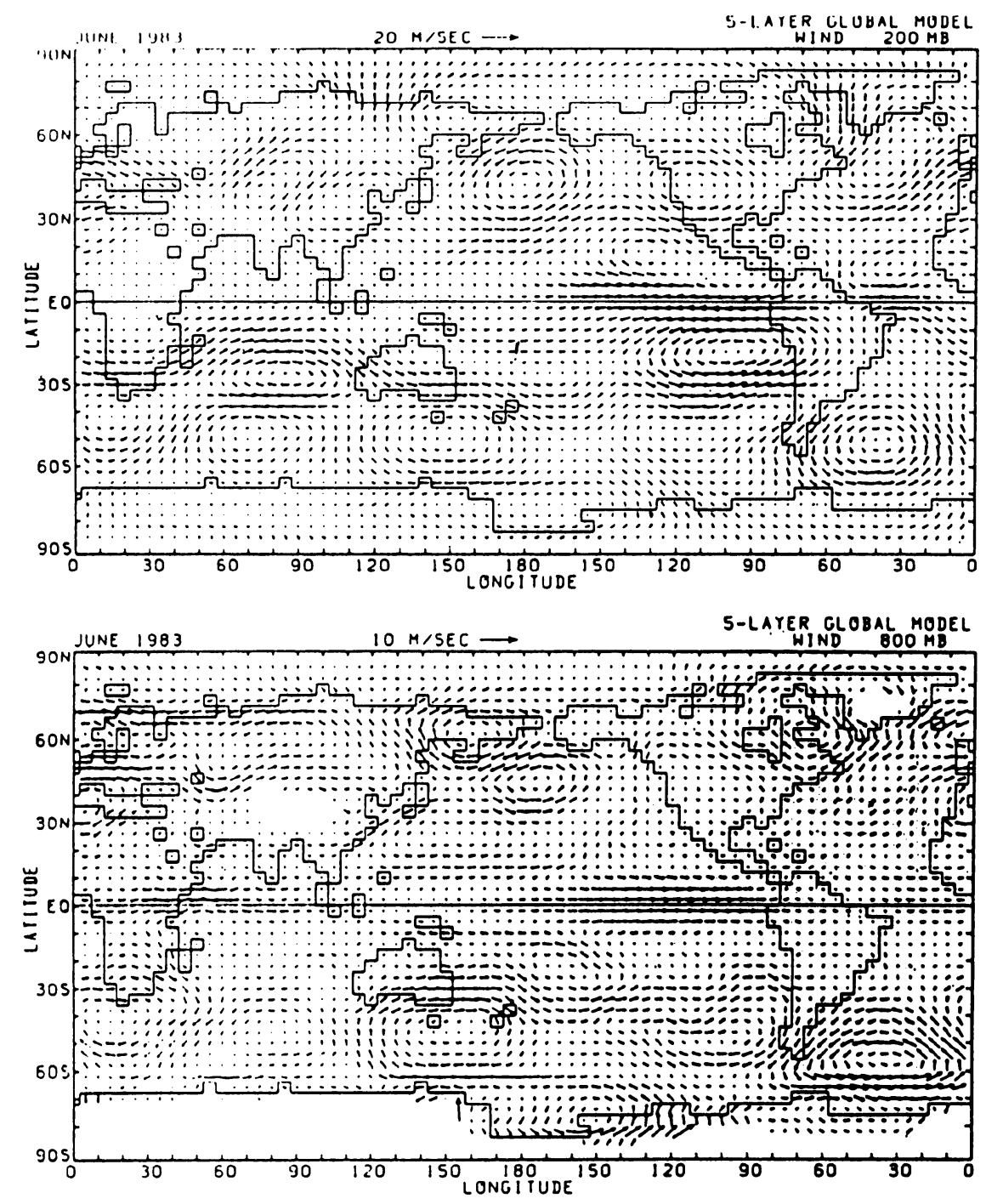

Fig. 29. Monthly mean anomalous circulation during the June 1983 at $200 \mathrm{mb}$ (upper panel) and $800 \mathrm{mb}$ (lower panel) in the MRI GCM (adopted form Tokioka et al., 1985). 

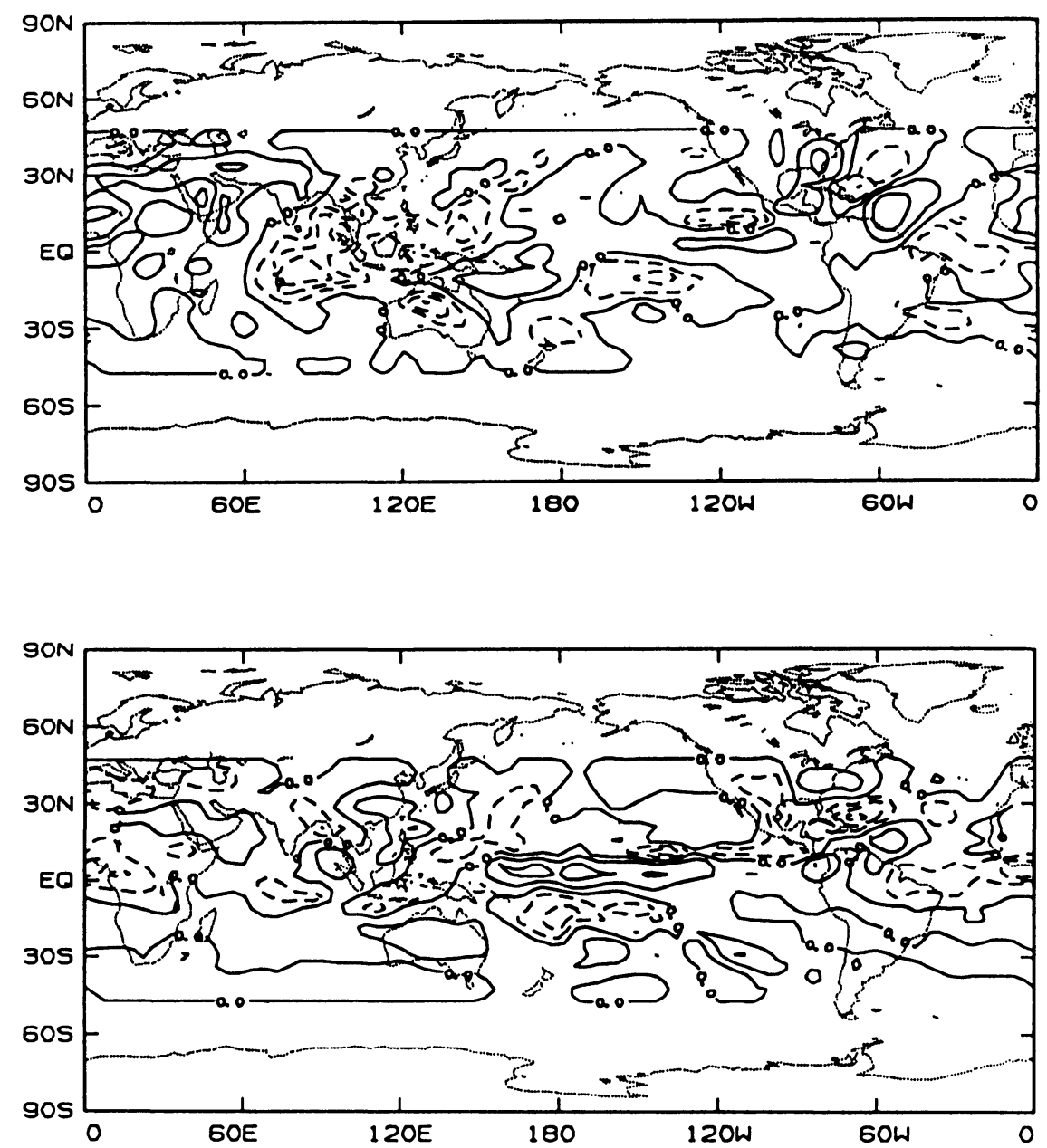

Fig. 30. Deviation of OLR from climatological mean for (a) May, 1988 and (b) June 1988. Contour interval is $8 \mathrm{Wm}^{-2}$.

of the barotropic model for June mean flow with May and June respectively. It is obvious that the ANA pattern is the dominant pattern in the northern hemisphere in both cases. The stronger EAM heating in May is responsible for the ANA pattern as well as a stronger subtropical response in the region from northern Indian to the southern Indian Ocean. In addition, the May heating also causes a stronger southern hemisphere wavetrain in the South Pacific. Although the subtropical response in the India Ocean is reversed between June and May, the ANA pattern in both cases have the same sign. It should be noted that the simulated wave train in the western hemisphere is out of phase with the observed anomaly during the same period in which North America experienced a severe drought ( $c f$. Trenberth et al., 1990). It is likely that the phase of the ANA over the western hemisphere can be further influence by local forcing mechanism over the eastern North Pacific and North America. To identify the region of maximum sensitivity to the ANA pattern, we describe the following series of experiments with June heating restricted to the following region:
Case I: the eastern hemisphere, $0^{\circ}-180^{\circ}$

Case II: the large scale monsoon region i.e., $95^{\circ} \mathrm{E}-$ $180^{\circ}$

Case III: the EAM region, i.e., $95^{\circ} \mathrm{E}-140^{\circ} \mathrm{E}$

Case IV: the western Pacific, i.e., $140^{\circ} \mathrm{E}-180^{\circ}$

Figure 32 show the responses of the barotropic model for the different cases respectively. In Case I, the tropical and extratropical northern hemisphere response is practically the same compared to Fig. 31 (lower panel) for the full distribution of tropical forcing (contour interval in Fig. 32 is one-half of that in Fig. 31). From this, it is clear that the tropical heating in the eastern hemisphere is primarily responsible for the maintenance of the ANA pattern. When the heating is confined to the large scale monsoon region (Case II), the tropical response is different only in the region between $0^{\circ}$ to $95^{\circ} \mathrm{E}$, where the tropical forcing has been taken out. The far field responses in both hemispheres are essentially unchanged. This means that the teleconnection patterns are dependent only on the forcing within the large scale monsoon region. Finally, the monsoon 

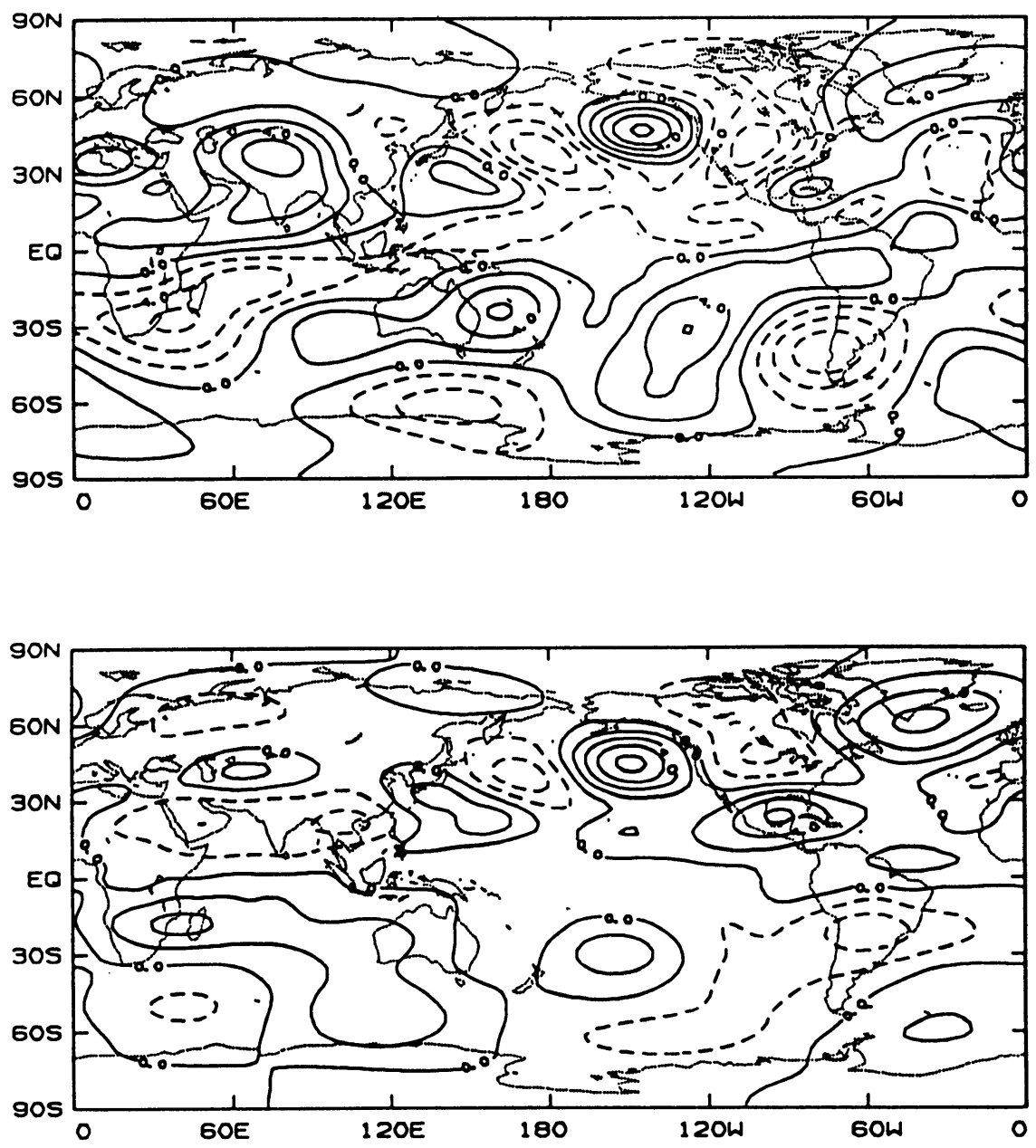

Fig. 31. Response of a barotropic model with climatological June mean flow to tropical heating derived from the OLR anomalies for May, 1988 (upper panel) and June 1988 (lower panel). Contour interval in units of $2 \times 10^{6} \mathrm{~m}^{2} \mathrm{~s}^{-1}$.

region is further subdivided into the EAM sector (Case III) and the western an central Pacific sector (Case IV). In Case III, the overall response is much weakened although the ANA pattern is still the only significant teleconnection pattern that can be discerned. When the hating is restricted to the western and central Pacific (Case IV), the far field response in the northern hemisphere again resembles the ANA, although the magnitude is somewhat weaker than the case with the full heating distribution. It is obvious that some of the difference in the above responses may be dependent upon the magnitude of the heating within the prescribed regions. For example, the anomalous heating is largest in the region covered by Case IV compared with the other regions. On the other hand, the similarity between Case I and the full heating case (Fig. 31b) suggests that the eastern Pacific heating is rather ineffective in exciting the ANA pattern. This may be due to the much smaller spatial scale of the heating in the eastern Pacific. The above results also suggest that the ANA is somewhat independent of the details of the heating within the eastern hemisphere, being most sensitive to heating within the western $\mathrm{Pa}$ cific. Recently Tsuyuki and Kurihara (1989) computed normal mode patterns of the northern hemisphere summertime circulation for August and June respectively. The ANA pattern is similar to their August normal mode pattern. The main difference is that the curvature of Tsuyuki and Kurihara's August wavetrain path is more or less along the 35-40 latitudue circle, while the ANA pattern here suggests an arching route along a great circle. Tsuyuki and Kurihara's June normal model features a wavetrain pattern similar to the observed pattern during June 1988, while the western Pacific portion of the wavetrain is shifted with respect of the observed. Thus there is still some uncertainties as to how well the ANA pattern can be applied to the specific case of June 1988. However, the above results suggest that the ANA pattern, may be at least a partial manifestation of a summertime normal mode pattern. More studies are required to unravel these uncertainties. 

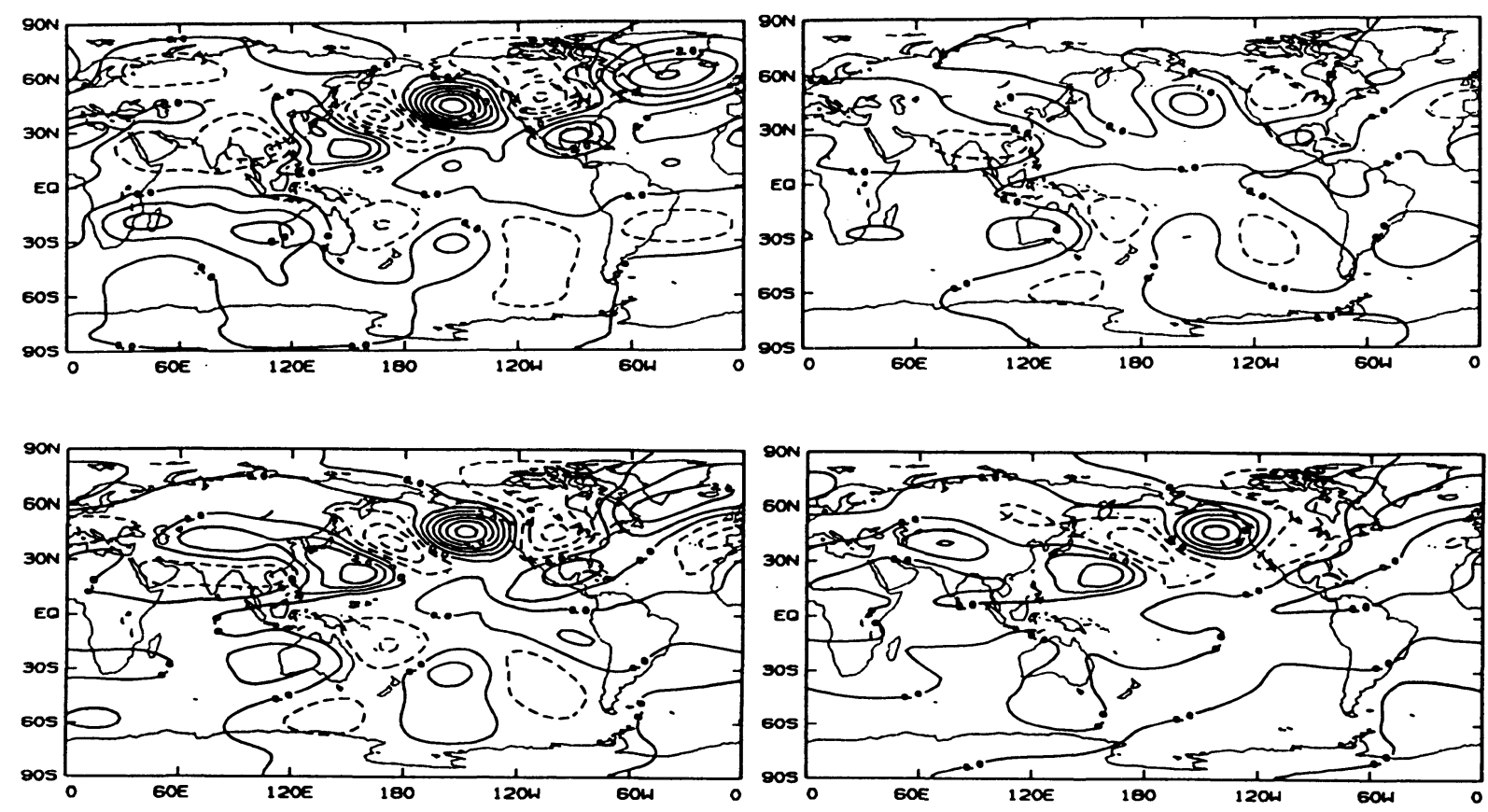

Fig. 32. Response of a barotropic model with climatological June mean flow to June tropical heating restricted to (a) $0-180^{\circ} \mathrm{E}$, (b) $95^{\circ} \mathrm{E}-180^{\circ}$, (c) $95^{\circ} \mathrm{E}-140^{\circ} \mathrm{E}$ and (d) $140-180^{\circ} \mathrm{E}$. Contour intervals in unit of $1 \times 10^{6} \mathrm{~m}^{2} \mathrm{~s}^{-1}$

\section{Conclusions}

It is clear from this review, that the EAM embodies a host of phenomena covering a diverse range of spatial and temporal scales. Some of the salient features of the EAM are summarized in the following.

- Monsoon rainfall over East Asia evolves with a wavetrain-like northward progression from May to September, with the major monsoon rainfall onset and withdrawal coinciding with different phases of the progression. The wavelike features are especially pronounced during the months of August to september. There are large intraseasonal and interannual variability associated with the EAM. In the intraseasonal scales, strong signals of the 30-60 day and 20 day oscillations are found in southern to central china. The amplitude of these oscillations decrease toward higher latitudes.

- In the interannual time scale, the biennial oscillation and the ENSO cycle are the predominant signals. It is found that EAM is dependent on the SST in the Kuroshio regions as well as basin-wide-wide SST anomalies which may be coupled to the ENSO. Above normal EAM rainfall is spearheaded by a warmer tropical Indian and Pacific Ocean and stronger meridional convergence of the surface wind in the equatorial eastern Pacific during the preceding winter. The above normal EAM rainfall is followed by a below normal SST in the Indian Ocean and the Pacific Ocean, and a much weaker tropical surface wind convergence during the subsequent winter. As a result, the basin-scale SST and surface wind undergo a switch in sign in approximately 12 month. These results suggest that the EAM is phase-locked to a basin-scale oscillation with a biennial time scale and perhaps play an important as a driver of this oscillation.

- There is an atmospheric teleconnection pattern linking the East Asian region to North American via the Aleutians. This mode is a normal mode pattern associated with a marginally unstable barotropic mode of the upper level northern summertime mean large scale circulation. This mode is related to heating in the equatorial Indian Ocean and western Pacific region. It is also possibly related to an observed forced wavetrain due to heating over the Philippines found by a number of previous studies.

- Recent theory and modeling works have shown that synoptic scale rainfall variability in EAM is due to heat induced unstable Rossby waves in the presence of vertical wind shear. Most interesting is the possibility that the EAM rainfall variability may be linked to multi-scale supercluster formation in the warm pool region of the equatorial western Pacific.

- GCMs have some successes in simulating the broad scale features of the seasonal transition 
of the EAM. However, they have limited capability in simulating the anomaly of the EAM arising from large scale SST changes.

One of the difficulties in the modeling studies of the summer monsoon is that most of the GCMs still have problems in getting the seasonal mean monsoon rainfall to occur in the right places. This is because the EAM rainfall distribution is the result of complex interactions between the atmosphere and the earth's surface and between tropical and extratropical systems involving a wide range of spatial and temporal scales from the mesoscale to the planetary scale. Model resolution and parameterizations in cumulus heating and boundary fluxes used in GCMs are still too crude to represent the monsoon rainfall realistically. Because there appears to be a six month lag between the largest SST anomaly and the EAM, in the study of the effect of SST on the monsoon, GCM integrations should be carried out with evolving SST starting in the preceding winter in order for the monsoon system to feel the full impact of the SST.

It is clear from this review that much work is needed to provide a more complete description of the spatial and temporal variability of the monsoon both in the intraseasonal and interannual times scales. Although theoretical and modeling work are beginning to shed some light on the mechanism of EAM variabilities, our understanding of the EAM is still very much in its infancy. We have seen evidence suggesting a relationship between interannual SST variation and the EAM; a link between supercluster organization in the warm pool of the western $\mathrm{Pa}$ cific and EAM synoptic scale variability and an influence of the EAM on North America summertime climate via atmospheric teleconnections. There may be other variabilities and teleconnections associated with the EAM that have not yet come to light. The teleconnection discussed in this paper and other possible links need to be further exploited and in order to unravel causal relationships and eventually to develop predictive skills for the EAM. Because of the expected growing number of GCM groups interested in working on the monsoon, there should also be increased effort in inter-model comparison, in addition to validation with observations.

\section{Reference}

Bretherton, C.S., C. Smith and J.M. Wallace, 1991: Singular value decomposition as a climate diagnostics technique. J. Climate (submitted).

Chang, C.P. and K.M. Lau, 1980: Northeasterly cold surges and near-equatorial disturbances over the winter MONEX area during December. Part II: Largescale aspects. Mon. Wea. Rev., 108, 298-312.

Chen, G.T.J. and C.P. Chang, 1980: The structure and vorticity budget of an early summer monsoon trough over South China and Japan. Mon. Wea. Rev., 108, 942-953.

Chen, L., J. Yang and G. Wang, 1989: The evolutional features of interannual low frequency oscillations and their relation to the occurrence of El Nino. Proc. US-PRC international TOGA symposium, Beijing, China.

Gill, A.E., 1980: Some simple solutions of heat-induced tropical circulation. Quart. J. Roy. Meteor. Soc., 106, $447-462$.

Hayashi, Y.Y. and A. Sumi, 1986: The 30-60 day oscillations simulated in an aqua-planet model. J. Meteor. Soc. Japan, 64, 451-467.

Huang, Ronghui, 1990: The East Asia/Pacific Pattern Teleconnection of summer circulation and climate anomaly in East Asia. Climate Change and Dynamics and Modelling, Eds. Zeng et al., China Meteorological press, $127-140$.

Jaeger, L., 1976: Monatskarten des Niederschlags fur die ganz Erde. Berichtge des Deutschen Wetterdienstes, 18, No. 139. Im Selbsverlag des Deutshcen Welterdienstes, Offenbach, W. Germany.

Keshvarmurty, R.N., 1982: Response of the atmosphere to sea surface temperature anomalies over the equatorial Pacific and the teleconnections of the Southern Oscillation.

Krishnamurti, T.N., 1985: Summer Monsoon Experiment-A Review. Mon. Wea. Rev., 113, 1590-1625.

Kurihara, K. and M. Kawahara, 1986: Extremes of East Asian weather during the post ENSO years of $1983 / 84$ - severe cold winter and hot dry summer. $J$. Meteor. Soc. Japan., 64, 493-503.

Kurihara, K. and T. Tsuyuki, 1987: Development of the barotropic high around Japan and its association with rossby wave-like propagations over the North Pacific: analysis of August 1984. J. Meteor. Soc. Japan, 65, 237-246.

Kurihara, K., 1989: A climatological study on the relationship between the Japanese summer weather and the subtropical high in the western North Pacific. $J$. Meteor. Soc. Japan, 43, 47-104.

Lau, A.K.H. and N.C. Lau, 1990: Observed structure and propagation characteristics of summertime synoptic scale disturbances over the tropical western $\mathrm{Pa}$ cific. East Asia and Western Pacific Meteorology and Climate. Eds. sham and Chang, world scientific Press, 48-57.

Lau, K.M., 1990: Seasonal and intraseasonal variations of the East Asian Summer monsoon. East Asia and Western Pacific Meteorology and Climate. Eds. Sham and Chang, World scientific Press, 94-104.

Lau, K.M. and L. Peng, 1991: Dynamics of atmospheric teleconnection during northern summer. J. Climate (accepted).

Lau, K.M., T. Nakazawa and C.H. Sui, 1991: Observations of cloud cluster hierarchies over the tropical western Pacific. J. Geophys. Res., Sp. Supplement, 96, 3197-3208.

Lau, K.M. and L. Peng, 1990: Origin of low frequency (intraseasonal) oscillations in the tropical atmosphere. Part III: Monsoon dynamics. J. Atmos. Sci., 40, 1443-1462. 
Lau, K.M., L. Peng, C.H. Sui and T. Nakazawa, 1989: Super cloud clusters, westerly wind burst, 30-60 day oscillations and ENSO: An unified view. J. Meteor. Soc. Japan, 67, 205-217.

Lau, K.M. and P.H. Chan, 1988: Intraseasonal and interannual variability of tropical convection: a possible link between the $40-50$ day oscillation and ENSO. $J$. Atmos. Sci., 45, 506-521.

Lau, K M., G.J. Yang and S. Shen, 1988: Seasonal and intraseasonal climatology of summer monsoon rainfall over east Asia. Mon. Wea. Rev., 116, 18-37.

Lau, K.M. and S. Shen, 1988: On the dynamics of intraseasonal oscillation and ENSO. J. Atmos. Sci., 45, 1781-1797.

Lau, K.M. and L. Peng, 1987: Origin of low frequency (intraseasonal) oscillations in the tropical atmosphere. Part I: the theory. J. Atmos. Sci., 44, 950-972.

Lau, K.M. and P.H. Chan, 1986: Aspects of the 40-50 day oscillation and during northern summer as inferred from outgoing longwave radiation. Mon. Wea. Rev., 114, 1354-1367.

Lau, K.M. and P.H. Chan, 1986: The 40-50 day oscillation and the El Nino/Southern Oscillation: a new perspective. Bull. Amer. Meteor. Soc., 67, 533-534.

Lau, K.M. and M.T. Li, 1984: The monsoon of East asia and its global associations-a survey, Bull. Amer. Meteor. Soc., 65, 114-125.

Lau, K.M. and P.H. Chan, 1983: Short-term climate variability and atmospheric teleconnection as inferred from satellite derived outgoing longwave radiation. Part I: Simultaneous correlations. J. Atmos. Sci., 40, 2735-2750.

Lau, K.M., C.P. Chang and P.H. Chan, 1983: Shortterm planetary scale interactions over the tropics and midlatitudes, Part I; Contrast between active and inactive periods. Mon. Wea. Rev., 110, 933-946.

Lau, K.M. and H. Lim, 1982: Thermally induced motions in an equatorial b-plane: Hadley and Walker circulation during the winter monsoon. Mon. Wea. Rev., 110, 336-353.

. Li, Chongyin, 1990: On interaction between anomalous circulation/climate in East Asia and El Nino Event. Climate Change and Dynamics and Modelling. Eds. Zeng et al., China Meteorological Press, 101-126.

Lin, Z., 1985: The Climate of China. Chinese Science Press, $254 \mathrm{pp}$

Li, M.T. and J.J. Lo, 1983: Abrupt changes associated with the East Asian summer monsoon large-scale circulation. Scientia Sinica, 2, 187-192.

Luo, H. and M. Yanai, 1983: The large scale circulation and heat sources over the Tibetan Plateau and the surrounding area during the early summer of 1979 . Part I: Precipitation and kinematics. Mon. Wea. Rev., 111, 922-944.

Murakami, M., 1983: Analysis of deep convective activity over the western Pacific and southeast Asia, I, diurnal variation. J. Meteor. Soc. Japan, 61, 60-75.

Nakazawa, T., 1988: Tropical cloud cluster within intraseasonal variations over the western Pacific. $J$. Meteor. Soc. Japan, 66, 823-839.

Ninomiya, K. and H. Muraki, 1986: Large scale circulations over East Asia during the Baiu period of 1979.
J. Meteor. Soc. Japan, 64, 409-429.

Nitta, T., 1986: Long term variations of cloud amount in the western Pacific region. J. Meteor. Soc. Japan, 64, 373-390.

Nitta, T., 1987: Convective activities in the tropical western Pacific and their impact on the northern hemisphere summer circulation. J. Meteor. Soc. Japan, 41, 373-390.

Palmer, T.N., C. Brankovic and P. Viterbo, 1990: Seasonal simulation of the summer monsoon by the ECMWF model with prescribed SST. Proc. International TOGA Scientific Conference. WMO/TD, No. 379, 217-225.

Rasmusson, E.M. and T.H. Carpenter, 1982: Variations in the tropical sea surface temperature and surface wind fields associated with the Southern Oscillation/El Nino. Mon. Wea. Rev., 111, 517-528.

Tokioka, T., J. Yanazaki and M. Chiba, 1985: Atmospheric response to the sea surface temperature anomalies observed in early summer of 1983: a numerical experiment. J. Meteor. Soc. Japan, 63, 565, 588 .

Trenberth, K., G. Branstator and P. Arkin: Origin of the 1988 North America drought. Science, 42, 16401645.

Tsuyuki, T. and K. Kurihara: Impact of convective activity in the western Tropical Pacific on the East Asian Summer Circulation. J. Meteor. Soc. Japan, 67, 231-247.

Wallace, J.M., C. Smith and C.S. Bretherton, 1991: Singular value decomposition of wintertime sea surface temperature and $500 \mathrm{mb}$ height anomalies. J. Climate (submitted).

Yasunari, T., 1988: Global teleconnection associated with the Indian monsoon and ENSO. Meteor. Res. Rep., University of Tokyo, 88-1, 30-38.

Yasunari, T., 1990: Monsoon and ENSO-a coupled ocean/land/atmosphere system. Proc. International TOGA Scientific Conference, Honolulu, Hawaii. WMO/TD No. 379, 111-120.

Zeng, Qingcun, Yuan Chongguang, Zhang Xuehong, Liang Xinzhong, Bao Ning, Wang Wanqui and Lu Xianchi, 1990: IAP GCM and its application to climate studies. Climate Change Dynamics and Modelling. Eds. Zeng et al., China Meteorological Press, 303-372. 


\title{
東アジア夏季モンスーンの降水変動とテレコネクション
}

\author{
K.-M. Lau \\ ( Laboratory for Atmospheres, NASA/Goddard Space Flight Center, USA )
}

\begin{abstract}
本論文では、東アジア夏季モンスーン（EAM） と全球の気候変動に及ぼす影響に関する最近の研究の レビューを行った。このレビューでは特に EAM の降水変動の特徴と、東アジアや全球の大気循環との関 係について重点を置いた。EAMの降水活動は、気候学的には 4-5月に中国南部から始まり、6月中旬に中 国中部に達する “梅雨前線” の北上に大きく支配されている。梅雨前線は中国中部に 1 2 週間停滞した後、 急激に消滅し、代わって新しい降水帯が中国北部に発生する。その後、大陸中部では約 20 日周期の降水変
\end{abstract} 動が現れる。これと同時に多降水域が再び中国南部及び南東部の海岸領域に戻る。

EAM 変動の特徵としては、モンスーン期間が非常に長く続くこと（4月から 8 月末まで)、主要な降水 帯が北上すること、複数のオンセットがあること、降水域が伝播性と停滞性の両方の特性を持っているこ と、を指摘することができる。EAM に直接影響を与える大規模場としては、西太平洋严熱帯高気圧、チ ベット高気压、地域的ハドレー循環、赤道域のウォーカー循環がある。

$\mathrm{EAM}$ 降水変動は、一方、北半球夏季に赤道イント洋-西太平洋から $\mathrm{EAM}$ 域及びインド大陸に向かって 北上する全球規模降水変動の一部に過ぎないEAM は、季節変化、季節内振動、様々な季節内変動現象間 の相互作用、中・小規模擾乱、西太平洋の超雲集団等、様々な時・空間規模の変動で成り立っている。こ れらの変動は、準 2 年振動やエルニーニョ・南方振動に伴う年々変動と密接に関係している。

次に、北太平洋を経由して東アジアから北米につながるテレコネクション（ANA）について、議論を 行った。ANA は日本を含む東アジアの天候に大きな影響を与えている。これは力学的には北半球夏季の平 均流の弱い順圧不安定と関係しているものと思われる。また、この变動はフィリピンやインド洋の対流活 動とも関連している。

大気大循環モデル（GCM）によって、全球規模の ANA はある程度再現できているが、東アジアやイ ンドの地域的降水変動は十分表現できていない。また、EAMの季節内変動や年々変動も GCM ではそれ ほど良く再現されていない。EAM 変動のモデル化には今後も一層の研究が必要である。 